Maurice A. Deane School of Law at Hofstra University Scholarly Commons at Hofstra Law

Hofstra Law Faculty Scholarship

2015

\title{
Intellectual Property Infringement as Vandalism
}

Irina D. Manta

Maurice A. Deane School of Law at Hofstra University

Robert E. Wagner

Follow this and additional works at: https://scholarlycommons.law.hofstra.edu/faculty_scholarship Part of the Law Commons

\section{Recommended Citation}

Irina D. Manta and Robert E. Wagner, Intellectual Property Infringement as Vandalism, 18 Stan.Tech.L.Rev. 331 (2015)

Available at: https://scholarlycommons.law.hofstra.edu/faculty_scholarship/1158

This Article is brought to you for free and open access by Scholarly Commons at Hofstra Law. It has been accepted for inclusion in Hofstra Law Faculty Scholarship by an authorized administrator of Scholarly Commons at Hofstra Law. For more information, please contact lawcls@hofstra.edu. 


\title{
INTELLECTUAL PROPERTY INFRINGEMENT AS VANDALISM
}

\author{
Irina D. Manta* \& Robert E. Wagner**
}

Cite AS: 18 StAn. TECH. L. REV. 331 (2015)

http://stlr.stanford.edu/pdf/ipvandalism.pdf

\begin{abstract}
Defenders of strong intellectual property rights often maintain that intellectual property infringement is theft and that the sanctions associated with it ought to be high. Others are skeptical of the property comparison and think that much lower sanctions are appropriate. In this Article, we argue that a careful analysis demonstrates: 1) that intellectual property infringement can be analogized to a property crime, but 2) that the more analogous crime is vandalism or trespass rather than theft. This categorization takes the rhetorical punch out of the property comparison.

In addition to analyzing the natures of the various offenses, this Article investigates the sanction regimes for different property violations and finds that not only are maximum statutory sanctions generally higher for intellectual property infringement than for vandalism and trespass, but they are also usually
\end{abstract}

\footnotetext{
* Associate Professor of Law and Director of the Center for Intellectual Property Law, Maurice A. Deane School of Law at Hofstra University; Yale Law School, J.D.; Yale College, B.A.

** Assistant Professor of Law, CUNY Baruch College Zicklin School of Business Department of Law; University of Chicago Booth School of Business, M.B.A.; Cornell Law School, J.D. We would like to thank Jonas Anderson, Clark Asay, Jane Bambauer, Will Baude, Chris Beauchamp, Jack Beermann, Michael Burstein, Jorge Contreras, Stacey Dogan, Greg Dolin, Janet Freilich, Brian Frye, Stuart Green, Christine Hurt, Keith Hylton, Orin Kerr, Jessica Kiser, Brian Lee, Oskar Liivak, Jake Linford, Michael Meurer, Christina Mulligan, Janewa OseiTutu, Amelia Rinehart, Cassandra Robertson, Jason Robison, Andres Sawicki, Jessica Silbey, Jeremy Sheff, Erin Sheley, Gordon Smith, Rebecca Tushnet, and the participants of the Boston University School of Law Intellectual Property Speaker Series workshop, George Washington University Law School \& U.S.P.T.O. Works in Progress Intellectual Property Colloquium, Intellectual Property Law Colloquium at the St. John's University School of Law, Junior Intellectual Property Scholars Workshop at the Florida State University College of Law, Law and Entrepreneurship Colloquium at Brigham Young University, Rocky Mountain Junior Scholars Forum at the University of Utah S.J. Quinney College of Law, and Junior Scholars Workshop at the Benjamin N. Cardozo School of Law, as well as our research assistant Allyson Beach. Our appreciation also goes to the Maurice A. Deane School of Law at Hofstra University as well as the CUNY Baruch College Zicklin School of Business Department of Law and their staffs for support during our research.
} 
higher than for theft. Bringing intellectual property infringement in line with property offenses, therefore, would actually result in a decrease in sanctions.

\section{TABLE OF CONTENTS}

INTRODUCTION.

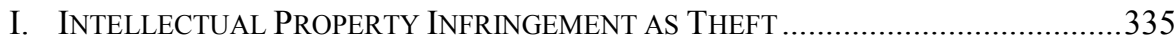

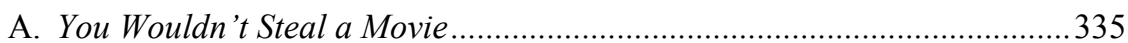

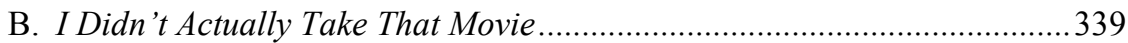

C. The Courts' Views on Intellectual Property Infringement as Theft.............340

D. Proper Propertization: IP Infringement as Vandalism or Trespass............342

II. THE STATUTORY FRAMEWORKS OF PROPERTY VIOLATIONS AND COPYRIGHT INFRINGEMENT

A. Sanctions for Theft, Vandalism, and Trespass in the State and Federal Systems

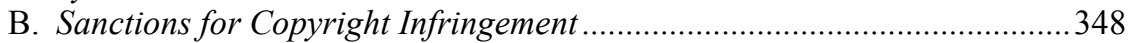

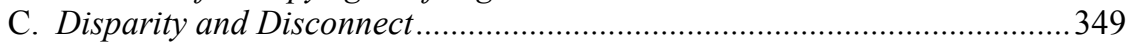

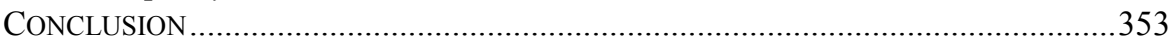

APPENDIX 1:

VALUE OF THEFT/DAMAGE \$1,000.01 TO \$2,500.00 (STATUTE IN

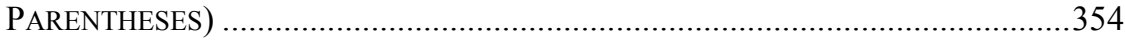
APPENDIX 2:

VALUE OF THEFT/DAMAGE \$2,500.01 OR MORE (STATUTE IN PARENTHESES)

\section{INTRODUCTION}

In one of the better-known ads that seek to draw attention to the gravity of intellectual property (IP) infringement, viewers are told: "You wouldn't steal a car. You wouldn't steal a handbag. You wouldn't steal a television. You wouldn't steal a movie. Downloading pirated films is stealing. Stealing is against the law. Piracy. It's a crime." ${ }^{1}$ Often without much subtlety, content owners have for years tried to convince society that copyright infringement amounts to the same immoral behavior as the theft of tangible goods. Owners seek to emphasize the fact that infringers take things of value and that, just like society does not tolerate this in the context of physical property, it should not have to tolerate it for intellectual property. ${ }^{2}$ The rhetoric of these content

1. Piracy It's a Crime, YouTuBE (Dec. 4, 2007),
https://www.youtube.com/watch?v=HmZm8vNHBSU. Ironically, it is unclear whether this
warning against copyright infringement was uploaded to YouTube with permission. The
video was used as a trailer screened in movie theaters and was developed in collaboration
between the Motion Picture Association of America (MPAA) and the Intellectual Property
Office of Singapore (IPOS). Be HIP at the Movies, IPOS (July 27, 2004),
http://web.archive.org/web/20040804074635/http://www.ipos.gov.sg/main/newsroom/media
rel/mediarelease1_270704.html.
2. For a discussion of this trend, see Neil Weinstock Netanel, Impose a
Noncommercial Use Levy to Allow Free Peer-to-Peer File Sharing, 17 HARV. J.L. \& TECH.
1, 22 (2003) (criticizing the content industries for using "the rhetoric of private property to


owners is not novel; to the contrary, the term "property" has been applied in relation to IP throughout American history, although the frequency of its use remains disputed. ${ }^{3}$

On the other side of this debate stand a number of scholars and activists who are quick to point out the multitude of differences between intellectual property infringement and theft. ${ }^{4}$ When an object is stolen, the owner is completely deprived of it, whereas the owner retains an integral copy of a work when intellectual property infringement occurs. ${ }^{5}$ Unlike in the case of regular theft, the intellectual property owner can also continue to sell copies of this work to willing buyers, provided the market will bear it. ${ }^{6}$ Furthermore, to the

support their lobbying efforts and litigation").

3. See generally Justin Hughes, Copyright and Incomplete Historiographies: Of Piracy, Propertization, and Thomas Jefferson, 79 S. CAL. L. Rev. 993 (2006); Adam Mossoff, What is Property? Putting the Pieces Back Together, 45 ARIZ. L. Rev. 371, 426 (2003) ("Copyright is defined and protected in the American legal system as a property right within the domain of intellectual property. Therefore, to connect copyright to the broader concept and institutional definition of property better grounds this legal doctrine within our legal system as such."). See also Richard A. Epstein, Liberty Versus Property? Cracks in the Foundations of Copyright Law, 42 SAN DIEGo L. REV. 1 (2005) (showing the parallels between the benefits and costs of the property system as compared to those of the copyright system). For a discussion of the relationship between property law and patent law, see, e.g., Adam Mossoff, The Trespass Fallacy in Patent Law, 65 Fla. L. Rev. 1687 (2013).

4. See generally Stuart P. Green, 13 Ways to Steal a Bicycle: Theft Law in the Information AGE (2012) [hereinafter "GrEEN, 13 WAYs"]. One of us has reviewed this work previously. See Irina D. Manta, 13 Ways to Steal a Bicycle: Theft Law in the Information Age by Stuart Green, 4 IP L. BooK REV. 11 (2014). This scholarly discussion takes place in the context of a broader debate about the value of propertizing IP. See, e.g., Michael A. Carrier, Cabining Intellectual Property Through a Property Paradigm, 54 DUKE L.J. 1, 4-5 (2004) ("As IP has lost its balance, it has increasingly come to resemble property. . . Many courts and companies today unquestioningly view property as justifying absolute rights of exclusion and a total lack of limits on IP holders."); David Fagundes, Crystals in the Public Domain, 50 B.C. L. REv. 139, 140 ("Every great story has a villain, and in the story told by enthusiasts of the public domain, that villain is property."); Jessica Litman, The Public Domain, 39 EMORY L.J. 965, 971 (1990) (criticizing the treatment of IP as property); Michael J. Madison, Legal-Ware: Contract and Copyright in the Digital Age, 67 FORDHAM L. REV. 1025, 1143 n.76 (accusing the propertization of IP rights of driving up transaction costs). But see Adam Mossoff, Is Copyright Property?, 42 SAN DiEgo L. Rev. 29, 34 (2005) (stating the possibility that "the Internet exceptionalists' complaint about extending copyright to digital media is, at the same time, neither informative nor instructive - unless one's goal is to restructure universally the concepts and legal rules for all property entitlements in American society"). This Article specifically focuses on the "theft" rather than the slightly different "piracy" label. For a discussion of the historical development of the latter, see generally AdRIAN JOHNS, PiRACY: THE INTELLECTUAL Property WARS From GuTENBERG TO GATES (2010).

5. See, e.g., James Boyle, The Public Domain: Enclosing the Commons of the MIND 62-63 (2008) (warning against the idea that "theft is theft" and explaining that while IP infringement creates losses, society should at most define new crimes to deal with those losses rather than apply the theft label), available at http://thepublicdomain.org/thepublicdomain1.pdf.

6. Indeed, even in situations that do not involve infringement, intellectual property owners will frequently grant nonexclusive licenses to multiple entities or individuals. See, e.g., Kenneth Ayotte \& Henry Hansmann, Legal Entities as Transferable Bundles of 
extent that the owner suffers a loss at the hands of the IP infringer, that loss is difficult to calculate. ${ }^{7}$ Not every infringer would have bought the work had he lacked the opportunity to infringe. ${ }^{8}$ At the same time, nobody can say with certainty about herself - even assuming perfect honesty-which works she would have bought in a zero-infringement world because the impulse to rationalize one's actions in this setting is strong.

The sphere that discusses intellectual property infringement is thus mostly split between two camps. One of them believes that infringement is theft and concludes that, if it is theft, the criminal sanctions and harsh civil sanctions that we have on the books are warranted. The other side denies that infringement is theft, sometimes downplays the gravity of infringement behavior, and generally believes that the level of sanctions that American IP law provides is unjustified.

This Article argues that the dichotomy that these two camps endorse is faulty, and that the question of whether intellectual property infringement parallels violations of property law requires more nuanced analysis before it can influence the calibration of sanctions for intellectual property infringement. ${ }^{9}$ This Article shows that there is little meaningful difference between intellectual property infringement and property violations, but that the question of whether infringement is "theft" has led to the creation of an unnecessarily confusing and polarized discussion framework. ${ }^{10}$ While many scholars are correct to state that intellectual property infringement is not and cannot be literally the same as theft for the reasons briefly delineated earlier in this Introduction, such infringement bears significant similarities to and few distinctions from lesser property-related offenses such as vandalism or, in some cases, trespass.

If one accepts the idea that IP infringement does at times parallel property violations, albeit not necessarily theft per se, the startling realization emerges that IP laws actually may punish wrongdoers more harshly than property law punishes defendants for equivalent offenses. After creating an analytical model

Contracts, 111 Mich. L. REv. 715, 750-51 (2013) (discussing some of the corporate issues that arise from such licenses).

7. Eric Goldman, A Road to No Warez, 82 OR. L. REv. 369, 426-30 (2003) (analyzing the difficulties inherent in infringement-related calculations of true losses).

8. Id. at 427.

9. Previous scholarly work has grappled with questions along those lines. See, e.g., Carrier, supra note 4 (suggesting that propertization can also serve limiting functions); Fagundes, supra note 4 (describing how propertization can provide greater legal clarity); Hughes, supra note 3, at 1054 (explaining that propertization should not be confused with commodification). This Article, however, is the first to focus on the infringement end of propertization and place such behavior on the spectrum of offenses that we criminalize in the world of tangible property.

10. Justin Hughes has stated that terms such as "theft" and "piracy" are often used loosely when we "sense that something 'belongs' to someone through some mechanismwhether legal, ethical, or social" even when no strict concept of property is in place. See Hughes, supra note 3, at 1010. He also believes that while the Founders did not enshrine the idea of property into the constitutional protection of IP, historical evidence suggests that notions of property provided a backbone for this constitutional framework. See id. at 1026. 
to determine the content of "equivalence" in this context, this Article demonstrates that adopting a truly property-oriented IP legal regime may actually mandate a view of lowered criminal and civil sanctions. By doing so, this Article shows how a rigorous understanding of what can be termed the "propertization" of IP may require a downward adjustment of today's punishments and other sanctions, especially in the area of copyright law.

The Article first sets out in Part I the main theories regarding the relationship between intellectual property infringement and property law violations and shows some of the flaws in the arguments both for and against the propertization of IP. Part II analyzes the criminal and civil frameworks under which American law punishes intellectual property and property offenses and points out the disparities between the two structures that result in the harsher punishment of intellectual property infringement. The final Part concludes.

\section{INTELLECTUAL PROPERTY INFRINGEMENT AS THEFT}

This Part examines how courts, scholars, content owners, and activists have treated the relationship between intellectual property infringement and property theft so far. As this Part demonstrates, both sides of the debate have generally provided an incomplete understanding of this relationship, which has led to a deadlock in the discourse on the topic. First, it is useful to analyze the arguments that have been made in favor of treating intellectual property infringement as theft. This Article will mainly focus on copyright in its discussions of intellectual property because (1) copyright infringement has been subject to theft rhetoric the most frequently and (2) that area of the law provides the richest statutory framework to which to draw comparisons.

\section{A. You Wouldn't Steal a Movie}

Content owners and organizations that seek strong protections for copyrighted goods have used the theft label for a long time and continue to do so. The Recording Industry Association of America (RIAA) explains prominently on its website that while copyright infringement is "commonly known as 'piracy,'... that's too benign of a term to adequately describe the toll that music theft takes on the enormous cast of industry players working behind the scenes to bring music to your ears." 11 The American government has often endorsed this same language, and the Federal Bureau of Investigation (FBI) states that "[p]reventing intellectual property theft is a priority of the FBI's criminal investigative program." ${ }^{2}$ The government, in conjunction with

11. RIAA, Who
http://www.riaa.com/physicalpiracy.php?content_selector=piracy_details_online (last visited
June 28, 2014).
12. FBI, It's an Age-Old Crime: Stealing, http://www.fbi.gov/about-
us/investigate/white_collar/ipr/ipr (last visited June 28, 2014).


MTV, also produced a music video that made the point unambiguously by showing artist Addie Brownlee singing in a New York City subway station as spectators take coins out of her guitar case. ${ }^{13}$ A narrator states: "When you download music illegally, you are stealing from musicians, songwriters, and people like Addie who are denied payment for work that is rightfully theirs." 14 In the United Kingdom, a trade organization named The Federation Against Copyright Theft (FACT) was established in 1983 and continues to operate in the interest of content owners. ${ }^{15}$

The key reason that content owners and their associates use the rhetoric of theft is that they want to emphasize the gravity of the conduct. The average downloader might tell herself that it makes little to no difference in the grand scheme of things if she illegally downloads music or movies, or if she shares such materials with friends and even a few strangers. ${ }^{16}$ Basically everybody, however, understands the concept of theft and has been raised to understand, often axiomatically, that stealing is wrong. ${ }^{17}$ Stealing can be defined in a few different ways, all of which have their advantages and flaws. ${ }^{18}$ For instance, within one understanding, stealing represents the taking of something that is not one's own. ${ }^{19}$ This quickly becomes circular, however, if one focuses on the fact that the law determines what is one's own, and the law may or may not do so in a way that is optimal or moral. ${ }^{20}$ Even property law does not deal in absolutes,

13. Ted Johnson, Effort Designed to Raise Awareness of Copyright Theft, VARIETY (Nov. 30, 2011), http://variety.com/2011/biz/news/government-unveils-anti-piracycampaign-1118046785/.

14. See id. The video is available at NCPC, It Hurts, YouTube (Nov. 29, 2011), https://www.youtube.com/watch?v=OOBC5kuDS5A.

15. About FACT, FACT, http://www.fact-uk.org.uk/about/ (last visited June 28, 2014).

16. See Geraldine Szott Moohr, The Crime of Copyright Infringement: An Inquiry Based on Morality, Harm, and Criminal Theory, 83 B.U. L. REV. 731, 771-73 (2003) (providing explanations for why many people do not view illegal downloading as immoral).

17. See John Hospers, Human Conduct: Problems of Ethics 12 (2d ed. 1982) ("Americans generally believe that stealing is wrong and that being caught and punished for stealing is all right, provided the punishment isn't too severe ...."); Robert Justin Lipkin, Beyond Skepticism, Foundationalism and the New Fuzziness: The Role of Wide Reflective Equilibrium in Legal Theory, 75 CORNELL L. REV. 811, 866 (1990) ("[T]he intuition that stealing is wrong expresses our desire not to let others interfere with our ownership or use of property.").

18. For a discussion of the definition of theft as a matter of historical development, see Michael A. Tigar, The Right of Property and the Law of Theft, 62 TEX. L. REV. 1443 (1984).

19. Roscoe Pound described this idea in the early twentieth century as one that had existed for a long time. Roscoe Pound, The End of Law as Developed in Juristic Thought, 27 HARV. L. ReV. 605, 613 (1914). See also GreEn, 13 WAys, supra note 4, at 73 ("The essence of theft and other property offenses is that they involve an offender's (wrongfully) causing harm to another's interests in, and rights to, property.").

20. See Yochai Benkler, Constitutional Bounds of Database Protection: The Role of Judicial Review in the Creation and Definition of Private Rights in Information, 15 BERKELEY TECH. L.J. 535, 591 (2000) (“' [S]tating that a law is needed because 'theft' will be rampant unless we pass the very law that converts what is now privileged use into 'theft' is circular."). Adherents of natural rights theory may argue that there is a concept of "one's own" that predates legal definitions. For a natural rights approach to intellectual property, 
and American law has doctrines that permit easements or the taking of property through adverse possession. ${ }^{21}$ Theft can also be defined as the taking of something of value from another party, but that does not resolve what constitutes "taking" and, again, which value that other party should be able to capture for himself in the first place. $^{22}$

If one were to ask content owners and other proponents of the "IP infringement as theft" theory to explain their views in greater detail, they would cite a number of factors that create parallels between the two types of violations. The IP owner, just like the property owner, generally mixes her labor with pre-existing materials to provide society with goods and help it flourish. ${ }^{23}$ She will sometimes, however, only do so if provided with a critical mass of remuneration, or at least that remuneration will affect her level of productivity and of her efforts to distribute her work. ${ }^{24}$ For the intellectual property owner, large-scale illegitimate distribution of her works economically creates the same effect as a horde of potato thieves does for a farmer. In the farmer's case, there will be nothing left to buy if all the potatoes are gone. In the infringer's case, even though the song will still "be" there in the end, few people may want to buy it if they can obtain it at zero cost elsewhere. ${ }^{25}$

Looking at it from the other end, the potato thief ends up with a good for which he provided no labor or other valuable effort in exchange. Thieves, by

see Wendy J. Gordon, A Property Right in Self-Expression: Equality and Individualism in the Natural Law of Intellectual Property, 102 YALE L.J. 1533 (1993). See generally Katrina Miriam Wyman, Problematic Private Property: The Case of New York Taxicab Medallions, 30 YALE J. ON REG. 125 (2013) (arguing that the property regime is a creature of the state and subject to the political influence of interest groups, which results in a mix of efficient and inefficient laws).

21. See generally Deepa Varadarajan, Improvement Doctrines, 21 GEO. MASON L. REV. 657 (2014). For an analysis of the relationship between trademark law and adverse possession, see Jake Linford, Trademark Owner as Adverse Possessor: Productive Use and Property Acquisition, 63 CASE W. Res. L. REV. 703 (2012).

22. See Stuart P. Green, Plagiarism, Norms, and the Limits of Theft Law: Some Observations on the Use of Criminal Sanctions in Enforcing Intellectual Property Rights, 54 HAstinGS L.J. 167, 216 (2002) (discussing the problems with the "thing of value" approach to theft).

23. For a discussion of Lockean notions of intellectual property related to this idea, see Justin Hughes, The Philosophy of Intellectual Property, 77 GEO. L.J. 287, 296-330 (1988).

24. See, e.g., Shyamkrishna Balganesh, Foreseeability and Copyright Incentives, 122 HARV. L. REV. 1569, 1571 (2009) ("Copyright law's principal justification today is the economic theory of creator incentives."). Other scholars have noted that non-monetary incentives to create exist as well. See generally Jeanne C. Fromer, Expressive Incentives in Intellectual Property, 98 VA. L. REV. 1745 (2012). Professor Peter DiCola's argues, on the basis of empirical research, that copyright leads to a winner-take-all outcome and that most musicians do not benefit from the current legal regime. Peter DiCola, Money from Music: Survey Evidence on Musicians' Revenue and Lessons About Copyright Incentives, 55 ARIz. L. REV. 301 (2013).

25. The empirical evidence on the effect of illegal file sharing on music sales is mixed. See, e.g., Derek E. Bambauer, Exposed, 98 MinN. L. REV. 2025, 2050 (2014) (presenting the results of several studies on the matter and concluding that "[t]he evidence is unclear") (citations omitted). 
definition, free ride on others' efforts. ${ }^{26}$ Similarly, the IP infringer is just a few clicks away from illicit goods that he can obtain without, in turn, contributing to society. ${ }^{27}$ Had the infringer not downloaded the property illegally, for example, one of two things would have happened. For one, he may have bought the good legally and the owner would have made money. ${ }^{28}$ Alternatively, he may not have bought the good at all. In this second scenario, while the intellectual property owner would have felt no financial difference, the infringer would not have been free riding and would not have had the opportunity to distribute that good to people who would have purchased the good legally but for this opportunity. ${ }^{29}$ There is a further possible loss that arises from the fact that intellectual property can-contrary to popular wisdom - be rivalrous at times. In the case of trademarks, the fact that many people use fake Louis Vuitton bags will disincentivize legitimate buyers from buying that brand if they value exclusivity or fear being viewed as potential infringers themselves. ${ }^{30}$ In the copyright world, some legitimate buyers of concert tickets may no longer be willing to pay the same amount of money for what should have been an exclusive show if they know that illegal tapings of that show will circulate later. ${ }^{31}$ The more rivalrous intellectual property turns out to be in a given case, the more it resembles property and the more its infringement parallels theft.

26. Stuart P. Green, Introduction: Symposium on Thirteen Ways to Steal a Bicycle, 47 New ENG. L. REV. 795, 812 (2013) (describing ways in which thieves are free riders). This has also led Professor Green to draw parallels between intellectual property infringement and unjust enrichment. See GREEN, 13 WAYS, supra note 4, at 256.

27. Some scholars have discussed how, within the community of illegal downloaders, another form of free riding takes place among many users, which is to take files from others but not share any in turn-though this failure to redistribute reduces some of the legal culpability. See Lior Jacob Strahilevitz, Charismatic Code, Social Norms, and the Emergence of Cooperation on the File-Swapping Networks, 89 VA. L. REV. 505, 571-72 (2003) (discussing the factors that lead to this behavior).

28. See GREEN, 13 WAYS, supra note 4, at 255-56 (analyzing the issue of such lost profits within a theft framework). The case law and U.S. Federal Sentencing Guidelines recognize the complexity of optimally calculating the infringement amount in instances of copyright or trademark infringement. See, e.g., United States v. Trang Doan Hoang, 536 Fed. Appx. 583, 587-90 (6th Cir. 2013) (interpreting and applying the Guidelines on this subject).

29. Raymond Shih Ray Ku, Grokking Grokster, 2005 WIS. L. REV. 1217, 1254 (suggesting that a significant number of illegal downloaders fall into this category). This is not to say that this scenario could never occur with tangible property, such as if someone steals rotten, worthless potatoes from a farmer. We would like to thank Greg Dolin for his comments on this subject.

30. See Irina D. Manta, Hedonic Trademarks, 74 OHIO ST. L.J. 241, 247-49 (2013). See generally Shahar J. Dillbary, Famous Trademarks and the Rational Basis for Protecting Irrational Beliefs, 14 Geo. MAson L. ReV. 605 (2007); Deborah R. Gerhardt, Consumer Investment in Trademarks, 88 N.C. L. REV. 427 (2010).

31. This may not be the case for everyone because some concert goers will feel better knowing that a performance they plan to attend will also end up online. 


\section{B. I Didn't Actually Take That Movie}

There has been strong opposition to the idea that the harm to an intellectual property owner that originates in infringement can be equated to the plight of the potato farmer in the example used above. For one, critics have suggested that the intellectual property owner retains the original work at all times even if it is infringed, whereas theft deprives an owner of a good, including the ability to enjoy it himself or sell it to someone else. ${ }^{32}$ Second, it is virtually impossible to remove all value from a good even through a large-scale infringement operation, which again distinguishes this scenario from theft. ${ }^{33}$ Third, the individual culpability of a given infringer tends to be much smaller than the culpability of a thief. ${ }^{34}$ Even if an infringer would have bought an artist's work, she would have perhaps paid a few dollars in most cases given the high proportion of infringement that consists of illegal file sharing. Thus, a few dollars is the most that the IP owner is likely to lose. While many infringers together can occasion a large loss to a copyright owner, the infringers each tend only to chip away at the value of the work. Put differently, few infringers can truly be called the "cause" of a loss in this context, which is not true of thieves. ${ }^{35}$

Some have argued that, from a safety perspective, intellectual property infringement also tends to involve a much lower risk to the public than theft does because the latter could lead to physical altercations and the like. ${ }^{36}$ From a moral standpoint, a number of scholars have questioned what it means to say that what has become routine behavior for many is genuinely reprehensible. Scholars have argued that current intellectual property law makes infringers out of everyone, even people who do not engage in blatant behaviors like illegal

32. See GREEN, 13 WAYs, supra note 4 , at 256.

33. See id. We acknowledge, given that these kinds of offenses operate on a continuum, that the greater a percentage of the value an infringer takes, the more he begins to approximate the theft scenario.

34. See id. at 256-57.

35. See id.

36. See Christine Hurt, Of Breaches of the Peace, Home Invasions, and Securities Fraud, 44 AM. CRIM. L. REV. 1365, 1377 (2007) (explaining how property crimes such as robbery "threaten the sanctity of home and hearth"). This is, of course, not true of all property crimes. For instance, one exception is the electronic theft of bank funds. It is also worth noting that the concept of self-help does exist in intellectual property law, as evidenced by the various security measures that owners implement to protect their goods. See Christopher Buccafusco \& Jonathan S. Masur, Innovation and Incarceration: An Economic Analysis of Criminal Intellectual Property Law, 87 S. CAL. L. REv. 275 (2014) (arguing that criminal sanctions in intellectual property serve the purpose of limiting the amount of self-help in which owners engage via digital rights management technologies that hamper legitimate users). Lastly, there is the possibility that the risk of physical altercation provides a deterrent to potential criminals in the property context in a way that does not occur in intellectual property. We would like to thank the participants of the Intellectual Property Law Colloquium at the St. John's University School of Law for the helpful discussion on this topic. 
downloading. ${ }^{37}$ Tying that in with theft and the fact that the thief is generally viewed as an outcast of society who disrespects its rules, a concept of vast proportions of the population as thieves is puzzling. ${ }^{38}$

\section{The Courts' Views on Intellectual Property Infringement as Theft}

The most significant judicial pronouncement on whether intellectual property infringement represents a form of theft came in Dowling v. United States ${ }^{39}$ in which the Supreme Court ruled that a National Stolen Property Act (NSPA) provision that criminalized the interstate transportation of stolen property could not be used to punish actions involving bootleg records. ${ }^{40}$ The defendant in the case had transported bootleg phonorecords with copyrighted musical compositions by Elvis Presley, and the government argued that this unauthorized use of the musical compositions turned the phonorecords into goods that were "stolen, converted or taken by fraud" as understood by the NSPA. ${ }^{41}$ The Court rejected this interpretation and stated that "the copyright owner... holds no ordinary chattel. A copyright, like other intellectual property, comprises a series of carefully defined and carefully delimited

37. See, e.g., John Tehranian, Infringement Nation: Copyright 2.0 And You (2011) (describing the disconnect between copyright law and the norms of most Americans). Recent research suggests that even when it comes to illegal downloading, almost half of Americans - and as many as $70 \%$ of those aged eighteen to twenty-nine-likely engage in the behavior. See Joe KARAGANIS, Copyright Infringement and Enforcement in the US, AM. ASSEMBLy 2 (Nov. 2011), available at http://piracy.americanassembly.org/wpcontent/uploads/2011/11/AA-Research-Note-Infringement-and-Enforcement-November-

2011.pdf. See generally Mark F. Schultz, Reconciling Social Norms and Copyright Law: Strategies for Persuading People to Pay for Recorded Music, 17 J. InTELl. Prop. L. 59 (2009).

38. Some scholars have argued that instead of asking courts to mete out punishments, content owners should focus more attention on changing societal norms to encourage people to obey the law in the name of principles such as reciprocity. See Mark F. Schultz, Fear and Norms and Rock \& Roll: What Jambands Can Teach Us About Persuading People to Obey Copyright Law, 21 BeRKELEY TECH. L.J. 651 (2006). In any case, a number of experts believe that attempts to "make an example" of individuals guilty of infringement often meet with societal resistance and prove counterproductive in combating the behavior. See, e.g., Ben Depoorter et al., Copyright Backlash, 84 S. CAL. L. REV. 1251 (2011). See generally Paul H. Robinson \& John M. Darley, Justice, Liability \& Blame: Community Views AND THE CRIMINAL LAW (1996) (reviewing the empirical evidence regarding laws that are disconnected from community norms); Paul H. Robinson \& John M. Darley, Intuitions of Justice: Implications for Criminal Law and Justice Policy, 81 S. CAL. L. REv. 1 (2007) (arguing that criminal law should not try to reform people's intuitions of justice); Paul $\mathrm{H}$. Robinson et al., Realism, Punishment \& Reform [A Reply to Braman, Kahan, and Hoffman, "Some Realism About Punishment Naturalism"], 77 U. CHI. L. REv. 1611, 1613 (2010) ("[W] hatever the source of the judgments of justice, they are deeply embedded and not easily modified.").

39. 473 U.S. 207 (1985).

40. One of us discussed this case in previous work. See Irina D. Manta, The Puzzle of Criminal Sanctions for Intellectual Property Infringement, 24 HARV. J.L. \& TECH. 469, 47779 (2011) [hereinafter "Manta, Puzzle of Criminal Sanctions"].

41. 473 U.S. at 214-15. 
interests to which the law affords correspondingly exact protections." 42 Hence, the Court stated, copyright could not be equated with offenses such as theft, conversion, or the like. ${ }^{43}$ The Court specified that an infringer can neither physically control an asset nor altogether prevent the owner from using it. ${ }^{44}$ The Court also emphasized that criminalizing copyrighted materials in this manner did not seem to have been Congress's intent. ${ }^{45}$ The dissent, however, argued that the defendant's acts corresponded to forms of theft, conversion, and unauthorized use. ${ }^{46}$

Not all lower courts have followed Dowling in the context of theft. In particular, some courts have endorsed the view that intangible property can actually be stolen. Emphasizing the post-Dowling Congressional amendment to the NSPA that added the term "transmits" 47 to newly cover electronic transfers in commerce, a few courts held that the transfer of electronic documents ${ }^{48}$ or interstate transportation of stolen software ${ }^{49}$ met the NSPA's requirements. One decision even stated several times that a defendant "physically stole" software when he loaded his employer's software program onto his laptop computer and then transported the program in electronic form on his computer in interstate and international commerce. ${ }^{50}$ In that case, simply copying a program was enough for the defendant's actions to qualify as theft.

These types of cases suggest that either (1) the lower courts have failed to follow Dowling, (2) some lower courts believe that the addition of the "transmits" language significantly changes the message of Dowling, or (3) Dowling did not truly reject the idea that intangible goods protected by copyright or by other types of intellectual property can be stolen or converted. ${ }^{51}$ The Supreme Court may eventually decide a case that will clarify its understanding of this area of the law, although the addition of the "transmits" term appears to suggest that in Congress's opinion, the improper taking and transfer of intellectual property fits in with other property-related crimes like theft. ${ }^{52}$ In the meantime, courts certainly continue to fairly casually refer to "intellectual property theft" as a concept. ${ }^{53}$

\footnotetext{
42. Id. at 216 .

43. Id. at 217-18.

44. Id. at 217 .

45. Id. at 220-26.

46. Id. at 232 (Powell, J., dissenting).

47. 18 U.S.C.A. $\S 2314$ (West 2013).

48. See, e.g., United States v. Farraj, 142 F. Supp. 2d 484, 490 (S.D.N.Y. 2001).

49. See, e.g., United States v. Alavi, No. CR07-429-PHX-NVW, 2008 WL 1971391, at *2 (D. Ariz. May 2, 2008). But see United States v. Brown, 925 F.2d 1301, 1307 (10th Cir. 1991) (explaining that the Dowling holding removed every form of intangible property from the purview of the NSPA).

50. Alavi, 2008 WL 1971391, at*2.

51. See Manta, Puzzle of Criminal Sanctions, supra note 40, at 479.

52. Id.

53. A search on June 28, 2014 of the ALLCASES database on Westlaw revealed thirty-one instances in which a court used the phrase "intellectual property theft" or "ip
} 


\section{Proper Propertization: IP Infringement as Vandalism or Trespass}

The difficulties that have arisen in the debate over whether intellectual property infringement is theft originate in a number of causes. Content owners know that the message "intellectual property infringement is [a property offense lesser than theft]" does not pack the same rhetorical punch as their current statements. Opponents of the present rhetoric, however, are correct when they point out that infringement rarely removes all value, which distinguishes it from theft. ${ }^{54}$ Meanwhile, there are other types of offenses against physical property that characterize actions resulting in the partial reduction of the value of goods. The most prominent of these is vandalism. ${ }^{55}$ Vandalism involves the destruction rather than removal of property. "The idea behind criminal punishments for offenses such as vandalism and conversion is that ownership extends further than the simple holding of legal title to a good and the ability to transfer such title." 56 The concept of vandalism does not suffer from the majority of flaws that open up to attack the analogy to theft. Vandalism, by definition, does not require a complete removal of the good or of its value. The owner may still retain the ability to sell or license the good. Additionally, in some cases, both intellectual property infringement and vandalism have the potential to enhance rather than reduce the value of goods. ${ }^{57}$

theft." A Google search of the phrase "intellectual property theft" yields 219,000 results and of the phrase "ip theft" 122,000 results. Mark Lemley notes that the phrase "intellectual property" itself has observed an increase in use in judicial opinions. See Mark A. Lemley, Property, Intellectual Property, and Free Riding, 83 TEX. L. REV. 1031, 1033-34 (2005).

54. See supra note 33 and accompanying text.

55. See Manta, Puzzle of Criminal Sanctions, supra note 40, at 475.

56. Id.

57. Art vandalism is a great example of a crime in which an action crosses over from property into the realm of what copyright protects and which can result in either increased or decreased value. In a recent case involving vandalism against a graffiti work-which is generally viewed as its own form of vandalism - a man was subject to prosecution for defacing a Banksy creation. See Sheila V. Kumar, Man Charged with Second-Degree Felony for Vandalizing Banksy Graffiti, WALL ST. J. (Aug. 19, 2014), http://blogs.wsj.com/law/2014/08/19/man-charged-with-second-degree-felony-forvandalizing-banksy-graffiti/. Meanwhile, Banksy's original graffiti vandalism often results in huge gains for building owners. See, e.g., Scott Reyburn, Disputed Banksy Mural Sells for More Than \$1.1 Million, BloOMBERG (June 3, 2013), http://www.bloomberg.com/news/2013-06-02/disputed-banksy-mural-sells-for-more-than-11 -million.html. When it comes to intellectual property infringement, illegal downloading can allow users to discover music or TV shows and can then lead to increased purchases and hence profits for copyright owners. See, e.g., Thomas W. Joo, Remix Without Romance, 44 ConN. L. REv. 415, 475 (2011) ("Similarly, some copyright commentators defend unauthorized file sharing of copyrighted music on the ground that illegal downloads expose listeners to new music and thus have a positive marketing effect.") (citation omitted); Mike Hohnen, Study Confirms Illegal Downloads Increase Music Sales, MusicFeEds (Mar. 22, 2013), http://musicfeeds.com.au/news/study-confirms-illegal-downloads-increase-musicsales/; Sean Michaels, Study Finds Pirates 10 Times More Likely to Buy Music, GuARdian (Apr. 21, 2009), http://www.theguardian.com/music/2009/apr/21/study-finds-pirates-buymore-music. 
Of course, no analogy is perfect. Vandalism results in physical damage, while infringement does not affect the quality of the original good. Moreover, vandalism generally does not lead to monetary free riding, although it may bring non-financial enjoyment to the vandal. What generally matters most to the intellectual property owner, however, is the status of his good's value. ${ }^{58}$ Just as infringement can lower the value of an intangible good, so too can vandalism lower the value of a tangible one. One may further argue that vandalism must result in damage to be actionable. Indeed, there may be cases in which another form of property violation may provide an even better parallel, and that is trespass.

There is usually no requirement that trespass actually create damage, and it can occur both on land and against chattels. The moral culpability of an illicit downloader of copyrighted goods - for those who wish to focus on the issue from that angle-will generally lie, at most, somewhere between that of a vandal and of a trespasser. We say "at most" because we recognize that vandals and trespassers may also make property owners feel unsafe, which is usually not the case with intellectual property infringers. ${ }^{59}$ The offenses covered by the Digital Millennium Copyright Act (DMCA), which involve the circumvention of technological protection devices as well as the production and dissemination of anti-circumvention technologies, may provide a particularly apt analogy to trespass because they, too, involve a possible "intrusion" that may not carry actual economic harm. ${ }^{60}$

Having the public and courts use the mental model of vandalism or trespass as they think about copyright infringement poses some difficulties for the content owner, especially in the context of non-commercial infringement. One big problem that content owners face is the cost of pursuing infringers. ${ }^{61}$ Indeed, the "thief" label precisely obscures the important fact that no single perpetrator of non-commercial infringement is responsible for much damage at

58. There are certainly exceptions, however, in that some IP owners view infringement as a larger moral issue. In the context of alleged intellectual property infringement by a competitor, Steve Jobs told his biographer: "I will spend my last dying breath if I need to, and I will spend every penny of Apple's $\$ 40$ billion in the bank, to right this wrong. I'm going to destroy Android because it's a stolen product. I'm willing to go thermonuclear war on this." Josh Lowensohn, Jobs' 'Thermonuclear War' Quote Fair Game in Court, Judge Says, CNET (June 1., 2012), http://www.cnet.com/news/jobs-thermonuclear-war-quote-fairgame-in-court-judge-says/. We thank Brian Lee for his comments on this subject.

59. See supra note 36 and accompanying text.

60. For a discussion of the criminal sanctions contained in the DMCA, see the text accompanying notes 118-19, infra. See generally Adam Mossoff, The Trespass Fallacy in Patent Law, 65 FLA. L. REV. 1687 (2013) (explaining why trespass may not be as different from patent infringement as some critics have posited). One difference worth noting between copyright infringement and offenses such as vandalism and trespass is that the latter two generally do not occur on as large a scale. We would like to thank Chris Beauchamp for his comments on this topic.

61. See, e.g., Mark A. Lemley \& R. Anthony Reese, Reducing Digital Copyright Infringement Without Restricting Innovation, 56 STAN. L. REV. 1345, 1352 (2004) (acknowledging the cost of copyright enforcement). 
all. ${ }^{62}$ At most, that perpetrator is a vandal or trespasser, and how much of a punishment does an individual like that deserve? How much should he owe a content owner by way of restitution? ${ }^{63}$ Indeed, how much damage does a single commercial infringer cause? Even she is more of a vandal than a thief for the reasons delineated above.

The next Part of this Article will analyze the statutory framework surrounding property violations and contrast it with the laws that punish copyright infringement. This analysis will show that, while individual perpetrators are more culpable in theft scenarios and occasionally even in vandalism ones, copyright infringers frequently risk incurring higher penalties for their offenses than they would incur for the equivalent property violation.

\section{THE STATUTORY FRAMEWORKS OF PROPERTY VIOLATIONS AND COPYRIGHT} INFRINGEMENT

Most regulation of property violations is a creature of state law, while copyright law lives in the federal domain. Subpart II.A. will use relevant examples from state jurisdictions to make its case about the current status of the law of property violations in the United States. Subpart II.B. will then discuss the key statutes that deal with copyright infringement. As will become apparent in Subpart II.C., the law does not actually treat copyright infringers like trespassers, vandals, or sometimes even thieves. Rather, it often treats them worse than if they had committed property violations of that sort.

\section{A. Sanctions for Theft, Vandalism, and Trespass in the State and Federal Systems}

This Subpart will examine the current state of sanctions for property law violations in the United States. It will analyze both conventional theft statutes and statutes that criminalize the destruction or damage of property, such as by vandalism, as well as laws relating to trespass. Since most criminal laws of this type are in the province of the states rather than that of the federal government, this Article will focus on the laws of some of the largest jurisdictions in the United States, namely California, New York, and Texas. ${ }^{64}$

California divides theft into two categories: grand theft and petty theft. If a defendant is convicted of grand theft—-defined as theft of money, labor, or real or personal property with a value over $\$ 950^{65}$ - , she may be punished by imprisonment in a county jail not exceeding one year and a fine of $\$ 5,000 .{ }^{66}$

62. See supra note 34 and accompanying text.

63. Note that this Article uses the term "desert" as part of a larger utilitarian framework rather than a retributivist one.

64. We provide two appendices at the end of this Article that list the statutes for all states as well as the maximum sanctions for the hypotheticals we discuss.

65. Cal. Penal Code $\S 487$ (West 2013).

66. Id. $\S 489$. 
Petty theft includes all other acts of theft ${ }^{67}$ and can be punished by a maximum of six months imprisonment in county jail and a $\$ 1,000$ fine. ${ }^{68}$

Meanwhile, vandalism is prosecuted under California Penal Code Section 594, which states that if one maliciously defaces, damages, or destroys another person's property without the consent of the owner, one is subject to penalties of up to one year in jail and $\$ 50,000$ in fines. ${ }^{69}$ In some cases, the defendant is also required to pay restitution to the victim, which may exceed the value of the property damaged. For example, in In re Alexander A., the defendant was forced to pay approximately four times the value of the property to return it to its pre-vandalism state. ${ }^{70}$ In short, the maximum base penalty for both general property damage and property theft in California is one year in jail, with possible additional time for various aggravating circumstances.

In New York, the classifications of theft and the potential sentences have many more gradations and depend upon the amount of money that a stolen item is worth. If the property involved in a theft is valued at over $\$ 1,000$ but less than $\$ 3,000$, then the crime is grand larceny in the fourth degree. ${ }^{71}$ Grand larceny in the fourth degree is a class E felony, ${ }^{72}$ and it is punishable by up to four years in prison. ${ }^{73}$ If the property's value is greater than $\$ 3,000$ but no more than $\$ 50,000$, then the crime is grand larceny in the third degree ${ }^{74}$ and is punishable by up to seven years in prison. ${ }^{75}$ If the value of the property is greater than $\$ 50,000$ but not more than $\$ 1,000,000$, then the crime is grand larceny in the second degree ${ }^{76}$ and is punishable by up to fifteen years in prison. ${ }^{77}$ Finally, if property valued over $\$ 1,000,000$ is stolen, then the crime is grand larceny in the first degree ${ }^{78}$ and is punishable by imprisonment for up to twenty-five years. ${ }^{79}$

The law in New York treats damage or destruction of personal property in a way similar to theft, but with different thresholds and punishments. Destroying property with a relatively low value is deemed criminal mischief in the fourth degree ${ }^{80}$ and is punishable by up to one year's imprisonment. ${ }^{81}$ If one destroys property with the damage totaling more than $\$ 250$, one commits

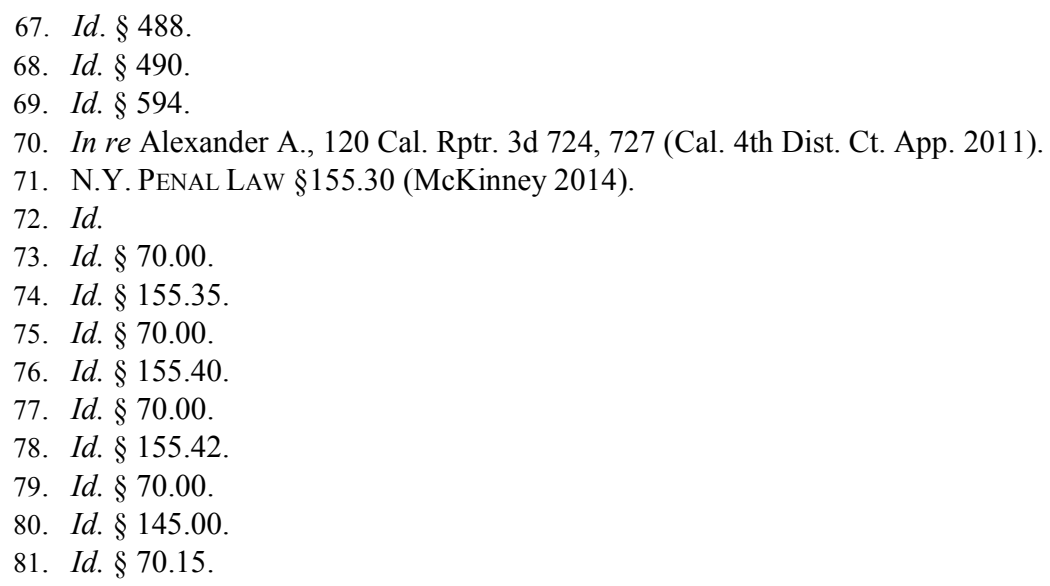


criminal mischief in the third degree (a class E felony) $)^{82}$ and faces a possible sentence of four years in prison. ${ }^{83}$ If the damage exceeds $\$ 1,500$, one commits criminal mischief in the second degree $^{84}$ and faces up to seven years in prison. ${ }^{85}$

Finally, in Texas, a sliding scale is used to determine an appropriate punishment for damage to personal property, with the amount of damage done dictating increased punishments again. If someone damaged someone else's property and the damage is less than $\$ 50$, then she has committed the class $\mathrm{C}$ misdemeanor of criminal mischief, ${ }^{86}$ and she will face a potential punishment of a fine not to exceed $\$ 500 .{ }^{87}$ The same crime is a class B misdemeanor if the amount of pecuniary loss is $\$ 50$ or more but less than $\$ 500,{ }^{88}$ in which case it carries a possible sentence of both a fine not to exceed $\$ 2,000$ and confinement in jail for up to 180 days. ${ }^{89}$ If the amount of damage is between $\$ 500$ and $\$ 1,500$, then the person has committed a class A misdemeanor ${ }^{90}$ and could face both a fine not to exceed $\$ 4,000$ and confinement in jail for up to one year. ${ }^{91}$

The next level of punishment in Texas is called a "state jail felony" and results if the amount of pecuniary loss is $\$ 1,500$ or more but less than $\$ 20,000,{ }^{92}$ in which case the defendant may be fined up to $\$ 10,000$ and sentenced to confinement in a state jail for any term of not more than two years. ${ }^{93} \mathrm{~A}$ felony of the third degree occurs if the amount of pecuniary loss is at least $\$ 20,000$ but no more than $\$ 100,000^{94}$ and carries with it a maximum sentence of imprisonment of not more than ten years and a fine not to exceed $\$ 10,000.9^{95}$ The next gradation of felony is a felony of the second degree. This involves an amount of pecuniary loss of $\$ 100,000$ or more but less than $\$ 200,000^{96}$ and carries a maximum sentence of imprisonment of not more than twenty years and a maximum fine of $\$ 10,000 .{ }^{97}$ Finally, a felony of the first degree exists if the amount of pecuniary loss is $\$ 200,000$ or more. ${ }^{98}$ Such an offense could carry a sentence as high as imprisonment for life or for any term

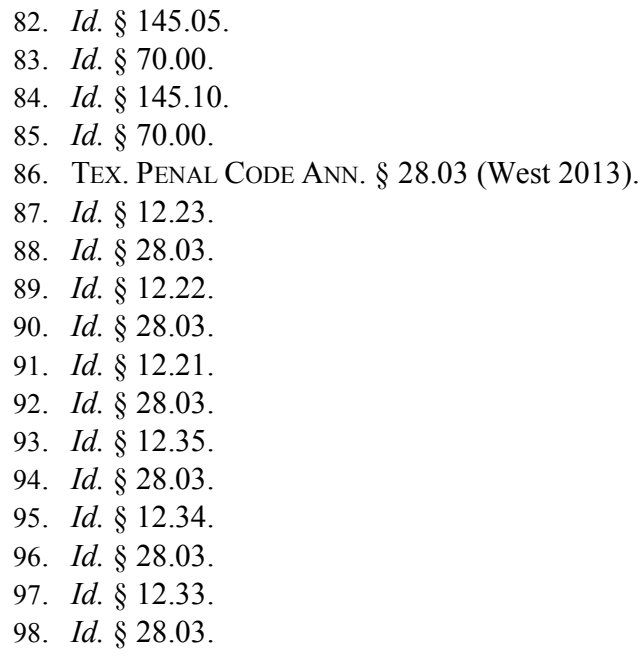


of not more than ninety-nine years in addition to a $\$ 10,000$ fine. ${ }^{99}$ Penalties for actual property theft also vary depending upon the value of the stolen goods. In fact, the severity of the punishment is the same whether the property has been damaged or stolen. For example, theft is a class $\mathrm{C}$ misdemeanor if the value of the property stolen is less than fifty dollars, and a felony of the first degree if said property has a value of $\$ 200,000$ or more. ${ }^{100}$

To sum up, in the states examined here, the maximum penalties for theft range from a sentence of six months and a $\$ 1,000$ dollar fine for petty theft in California to a sentence of ninety-nine years or life and a $\$ 10,000$ fine for stealing something worth more than $\$ 200,000$ in Texas. Similarly, crimes involving property damage have a maximum sentence of one year's imprisonment for a small amount of damage to property in New York and ninety-nine years in prison and a $\$ 10,000$ fine in Texas if the damage is over $\$ 200,000$.

There are also federal statutes that deal with thefts of various types. For example, in special maritime or territorial jurisdictions of the United States, if someone steals property worth more than $\$ 1,000$, that person may be fined and sentenced to imprisonment for up to five years. ${ }^{101}$ If the value of the item stolen is less than $\$ 1,000$, the maximum imprisonment term is lowered to one year. ${ }^{102}$ If someone steals from the United States (or any department/agency of the United States), then the punishment for stealing goods worth less than $\$ 1,000$ remains the same at one year's imprisonment. ${ }^{103}$ If the value of the stolen goods is more than $\$ 1,000$, however, the maximum is increased to ten years' imprisonment and a fine. ${ }^{104}$ One other example involving federal law deals with the theft of mail. If someone steals a letter from the post office (in any of a number of ways), that individual may be punished by a fine and imprisonment for up to five years. ${ }^{105}$

A different type of property offense often punished by the states is that of trespass. In California, basic trespass occurs when one enters upon any land belonging to someone else that is either surrounded by a fence or has no trespassing signs posted, and then refuses to leave when asked to do so. ${ }^{106}$ This offense is punishable by a fine not to exceed $\$ 100$ for the first offense and by a fine of up to $\$ 1,000$ and imprisonment for six months for all subsequent offenses. ${ }^{107}$ In Texas, trespassing involves going onto someone else's property without consent with the knowledge that entry was forbidden and refusing to

99. Id. $\S 12.32$.

100. Id. § 31.03 .

101. 18 U.S.C.A. $\S 661$ (West 2013).

102. $I d$.

103. Id. $\S 641$.

104. Id.

105. Id. $\S 1708$.

106. Cal. Penal Code $\S 602$ (West 2013).

107. Id. 
leave when asked. ${ }^{108}$ Violators of this Texas law may face a maximum sentence of a $\$ 2,000$ fine and confinement in jail for up to 180 days. ${ }^{109}$ In New York, a person commits trespass if she knowingly enters or remains unlawfully on any premises. ${ }^{110}$ If found guilty of this violation, she may be sentenced to a maximum prison sentence of fifteen days. ${ }^{111}$ In some circumstances, the federal government will also prosecute trespassers. For example, if someone goes onto any national forest land while it is closed to the public without the authority to do so, he may be fined and imprisoned for up to six months. ${ }^{112}$

\section{B. Sanctions for Copyright Infringement}

Federal law criminalizes the reproduction and distribution of copyrighted work. ${ }^{113}$ This offense occurs if a defendant reproduces or distributes, during any 180-day period, one or more copies of one or more copyrighted works, which together have a total retail value greater than $\$ 1,000 .{ }^{114}$ The defendant may face a possible punishment of imprisonment for no more than one year, and the punishment may increase to five years in prison if the retail value is over $\$ 2,500 .{ }^{115} \mathrm{He}$ may also be imprisoned for up to ten years if it is his second offense. ${ }^{116}$

Other federal crimes do not have any monetary values attached to them. For example, if a defendant records or distributes music without the consent of the owner, she may be subject to imprisonment for no more than five years for her first offense and no more than ten years for any second or other subsequent offense. ${ }^{117}$ There are also several violations to which criminal sanctions can attach under the Digital Millennium Copyright Act. One offense consists of circumventing or providing the means for others to circumvent various technological copyright protection measures. ${ }^{118}$ If a defendant is convicted of circumventing copyright measures, she may be fined up to $\$ 500,000$,

108. Tex. Penal Code AnN. $§ 30.05$ (West 2013).

109. Id. § 12.22 .

110. N.Y. PENAL LAW $\S 140.05$ (McKinney 2014).

111. Id. $\S 70.15$.

112. 18 U.S.C.A. $§ 1863$ (West 2013).

113. For a discussion of the political process that resulted in many of the copyright laws we have today, see Jessica D. Litman, Copyright, Compromise, and Legislative History, 72 CoRnell L. REV. 857 (1987). See also Pamela Samuelson \& Tara Wheatland, Statutory Damages in Copyright Law: A Remedy in Need of Reform, 51 WM. \& MARY L. ReV. 439 (2009) (critiquing on due process grounds the current system of statutory sanctions in copyright law).

114. 17 U.S.C.A. $§ 506(1)$ (B) (West 2014). One of us has discussed the constitutional problems inherent in the way that this and other statutes have been applied. See Irina D. Manta, Intellectual Property and the Presumption of Innocence, 56 WM. \& MARY L. REV. 1745 (2015).

115. 18 U.S.C.A. $\S 2319$ (b) (West 2013).

116. $I d . \S 2319(\mathrm{~b})(2)$.

117. Id. $\S 2319 \mathrm{~A}(\mathrm{a})$.

118. 17 U.S.C.A. $§ 1201$ (a) (West 2014). 
imprisoned for up to five years, or both for the first offense, and she could then be fined up to $\$ 1,000,000$ and imprisoned for ten years for any subsequent offense. ${ }^{119}$

While criminal sanctions tend to impose greater hardship on individuals than civil ones do, copyright law involves the possibility of significant civil statutory sanctions worth mentioning here. ${ }^{120}$ In most copyright infringement lawsuits, plaintiffs can elect to receive statutory damages of $\$ 750$ to $\$ 30,000$ per work rather than actual damages. ${ }^{121}$ If the infringement is deemed to have been willful, the statutory damages award can rise to as high as $\$ 150,000$ per work. ${ }^{122}$ A few copyright cases have attained national attention for their staggering total statutory awards. In one such case, a Minnesota woman named Jammie Thomas was ordered to pay $\$ 1.92$ million in damages for willfully and illegally sharing twenty-four copyrighted songs; these damages were later reduced to $\$ 222,000 .{ }^{123}$ Meanwhile, Boston University student Joel Tenenbaum was ordered to pay $\$ 675,000$ for illegally sharing thirty songs. ${ }^{124}$

\section{Disparity and Disconnect}

While, as discussed above, a number of scholars and content owners advocate for intellectual property to receive the same level of protection as property, few would openly say that, as a theoretical matter, it should receive more. In the discussions about intellectual property as property, the concept of property is generally viewed as a ceiling in that category. One would therefore expect that when it comes to sanctions, intellectual property infringement would at most be punished at the same level as property violations. This Article has shown that intellectual property infringement bears the most resemblance to vandalism and trespass. In the realm of sanctions, however, not only are the statutory criminal and civil sanctions generally higher for intellectual property infringement than those for vandalism, but they are also higher than those for downright property theft. ${ }^{125}$

119. Id. $\S 1204$.

120. As Kenneth Mann has discussed, depending on the circumstances, civil sanctions that-intentionally or not-take a punitive form have the potential to cause as much disruption to an individual's life as criminal sanctions. See Kenneth Mann, Punitive Civil Sanctions: The Middleground Between Criminal and Civil Law, 101 YALE L.J. 1795, 1798 (1993).

121. 17 U.S.C.A. § 504(c)(1) (West 2012).

122. Id. $\S 504(\mathrm{c})(2)$.

123. See Greg Sandoval, Appeals Court Sides with RIAA, Jammie Thomas Owes $\$ 222,000$, CNET (Sept. 11, 2012, 9:25 AM), http://www.cnet.com/news/appeals-court-sideswith-riaa-jammie-thomas-owes-222000/.

124. Sony BMG Music Entm’t v. Tenenbaum, 660 F.3d 487, 515 (1st Cir. 2011). Some scholars have argued that the current system of statutory sanctions goes so far in its lack of proportionality as to be unconstitutional. See Samuelson \& Wheatland, supra note 113, at 466-68.

125. This is not to say that the statutory maxima for theft are always higher than those for vandalism. 
One of the ways to make a comparison is to imagine a hypothetical good of a certain value and examine how it would be treated under the laws that relate to intellectual property versus property. As will become apparent, this exercise is not without its problems and perils, but it is informative nonetheless. Let us assume that an individual distributes a song illegally to 1001 other individuals. The song would normally cost $\$ 1$ to download legally. Had all 1001 individuals who obtained illegal copies bought the song in a legitimate fashion, its owner would have earned $\$ 1,001 .^{126}$ That being said, in this type of situation, undoubtedly not all 1001 people would have actually bought the song, so the harm to the song owner would be lower. ${ }^{127}$ Furthermore, one could argue that this distribution may constitute a proximate cause for future redistributions, which would bring about greater harm. The extent of this redistribution and of the role that the initial distributor played in its causation are difficult to predict, as is the number of people who would or would not have bought a given song legally. As a matter of approximation, let us therefore proceed with the figure of $\$ 1,001$ for the harm (the high end) but with no regard for subsequent harm involving redistribution. Indeed, that is the figure that copyright law would use to evaluate the gravity of the offense. Whether the action was taken for profit or not, a person guilty of this violation could go to prison for up to a year ${ }^{128}$ and be fined up to $\$ 100,000 .{ }^{129}$ If that individual distributed the song to 2501 people (thus causing a potential harm of $\$ 2,501$ ), she would face a maximum sentence of five years if she did it for profit or three years if she did not. ${ }^{130}$ She could also be fined up to $\$ 250,000 .^{131}$

What do maximum sentences look like in the context of theft and vandalism for offenses that deprive an owner of $\$ 1,001$ and $\$ 2,501$ of his property, respectively? Here are the maximum figures for theft:

\begin{tabular}{|l|l|l|}
\hline Theft & $\$ 1,001$ & $\$ 2,501$ \\
\hline California & $\begin{array}{l}\text { One year prison, } \$ 5,000 \\
\text { fine }\end{array}$ & $\begin{array}{l}\text { One year prison, } \\
\$ 5,000 \text { fine }\end{array}$ \\
\hline New York & $\begin{array}{l}\text { Four years prison, } \$ 5,000 \\
\text { or double profits fine }\end{array}$ & $\begin{array}{l}\text { Four years prison, } \\
\$ 5,000 \text { or double } \\
\text { profits fine }\end{array}$ \\
\hline Texas & $\begin{array}{l}\text { One year prison, } \$ 4,000 \\
\text { fine }\end{array}$ & $\begin{array}{l}\text { Two years prison, } \\
\$ 10,000 \text { fine }\end{array}$ \\
\hline
\end{tabular}

As one can see, the possible fines for intellectual property offenses vastly outpace the fines for property offenses. When it comes to prison offenses, the

126. To simplify, this hypothetical will assume that a single entity owns the song and profits from its sales.

127. See Goldman, supra note 7, at 427-28 (discussing the problems that lie with the assumption that each infringement represents a lost sale).

128. 18 U.S.C.A. § 2319(c)(3) (West 2013).

129. Id. § 3571(b)(5).

130. Id. $\S 2319$.

131. Id. $\S 3571(\mathrm{~b})(3)$. 
sentences on the intellectual property side are the same as or higher than all but one of the six possibilities in the table above (New York at $\$ 1,001$ has a higher prison sentence). Meanwhile, here are the figures for vandalism:

\begin{tabular}{|l|l|l|}
\hline Vandalism & $\$ 1,001$ & $\$ 2,501$ \\
\hline California & One year, $\$ 50,000$ & One year, $\$ 50,000$ \\
\hline New York & Four years & Seven years \\
\hline Texas & One year, $\$ 4,000$ & Two years, $\$ 10,000$ \\
\hline
\end{tabular}

Again, the fines for intellectual property offenses greatly exceed any of the fines for vandalism. The prison sentences are generally either the same or higher for intellectual property offenses, except in New York where vandalism leads to higher maximum prison sentences at both values.

When it comes to offenses under the DMCA, as mentioned previously, the maximum penalty for a first offense is a five-year prison sentence and $\$ 500,000$ in fines (figures that are not connected in the statute to the size of the economic harm). Here is the comparison to trespass on land:

\begin{tabular}{|l|l|}
\hline Trespass & Penalty \\
\hline California & \$100 fine \\
\hline New York & Fifteen days in prison, \$250 fine \\
\hline Texas & 180 days in prison, $\$ 2,000$ fine \\
\hline
\end{tabular}

Both the maximum prison sentence and fines that the DMCA carries are much greater than the possible penalties for trespass.

Overall, the pattern emerges that we do not actually treat intellectual property like property but rather often provide the option of harsher punishments for offenses against IP rights - sometimes dramatically so- than for those against tangible or real property rights. This disparity is made even more extreme when one considers the differences in the commission of the physical acts required for property offenses as opposed to those typically related to intellectual property infringement. For instance, to return to our earlier hypothetical, distributing a song to thousands of people need only take a few mouse clicks. Within seconds, an individual can make himself eligible for the highest sanctions under the criminal copyright laws. Within a few more seconds, he may have committed a second, separate offense that carries its own penalties. Meanwhile, stealing or vandalizing high-value goods generally takes quite a bit of effort and time (and may also involve the use of force). ${ }^{132}$ When

132. For a discussion of the relationship between theft and violence, see supra note 36 . Some have argued that the ease with which computer-related offenses can be committed militates for raising sanctions in that context to create "cost deterrence." See Neal Kumar Katyal, Criminal Law in Cyberspace, 149 U. PA. L. REV. 1003, 1006 (2001). One counterargument in the copyright context, however, is the issue that larger sentences are 
we consider the situation focusing on mens rea, the illicit distributor of files may act maliciously for five seconds and then realize that he acted inappropriately. ${ }^{133}$ Of course, shared files usually cannot be recovered. ${ }^{134} \mathrm{With}$ copyright infringement, a mens rea of very short duration can incur significant sanctions. After violations are committed and discovered, a prosecutor in a copyright case has a lot of discretion in how to stack charges and persuade offenders, who are intimidated by the high maximum punishments they face, to agree to harsh plea bargains. ${ }^{135}$

The disparities that we see between the property and intellectual property regimes may not be driven by a reasoned conclusion that intellectual property infringement is worse for society or more morally culpable than theft. Rather, as an initial matter, sanctions are often higher across contexts at the federal level than the state level for similar offenses. ${ }^{136}$ Second, owners of copyrighted (and trademarked) goods have over the years exerted a lot of pressure on the political process to maximize sanctions through a variety of bills. ${ }^{137}$ While the

increasingly in tension with community norms and actually create a backlash in individuals' responses to laws perceived as unfair. See supra note 38. It is also worth noting that while difficulty of detection may have once been a stronger argument in favor of high sanctions, many copyright infringers are now more easily identifiable than before. See, e.g., Brendan Sasso, Internet Providers Sent 1.3 Million Warnings to Alleged Pirates, NAT'L J. (May 28, 2014), http:/www.nationaljournal.com/tech/internet-providers-sent-1-3-million-warnings-toalleged-pirates-20140528 (explaining how the first ten months of the "six strikes" Copyright Alert System yielded 1.3 million infringement warnings, of which only 265 were challenged and no more than 47 were deemed erroneous). See generally Richard J. Gilbert \& Michael L. Katz, When Good Value Chains Go Bad: The Economics of Indirect Liability for Copyright Infringement, 52 HASTINGS L.J. 961, 963-68 (2001) (discussing the costs and benefits of various legal regimes in the area of illegal downloads). We appreciate Orin Kerr's and Brian Lee's comments on this topic.

133. Because mouse clicks happen so rapidly, many copyright infringers are unable to abort their attempts and avail themselves of the abandonment defense that arises in other legal contexts. See generally Robert E. Wagner, A Few Good Laws: Why Federal Criminal Law Needs a General Attempt Provision and How Military Law Can Provide One, 78 U. CIN. L. REV. 1043, 1070 (2010).

134. See Jake Linford, A Second Look at the Right of First Publication, 58 J. COPYRIGHT SOC'Y U.S.A. 585, 638-43 (2011). This issue also arises in non-property contexts such as criminal libel and slander. We would like to thank Jake Linford for his comments on this subject. We would also like to note that in at least some scenarios involving theft of physical objects, the goods may be recovered later. We thank Andres Sawicki for his related remarks.

135. One of us has discussed this issue in the context of the story of Aaron Swartz, who faced severe charges based on information offenses and committed suicide before his trial. See Irina D. Manta, The High Cost of Low Sanctions, 66 FLA. L. REV. 157, 194-200 (2014).

136. For example, Rachel Barkow has suggested that the states are more aware of the costs surrounding incarceration and other forms of law enforcement and therefore often take a more moderate approach. See Rachel E. Barkow, Federalism and the Politics of Sentencing, 105 CoLUM. L. REV. 1276, 1301 (2005). Indeed, as mentioned previously, federal theft and vandalism offenses are also punished more harshly, although that may stem in part from the federal government's strong desire for self-protection.

137. See Manta, Puzzle of Criminal Sanctions, supra note 40, at 505-12 (providing a public choice analysis of criminal sanctions in intellectual property). 
argument that intellectual property should be treated like property has been used many times to continue to increase sanctions, this Part shows that bringing intellectual property fully in line with property in the arena of sanctions would actually likely mean that the sanctions for intellectual property violations should be decreased rather than increased.

\section{CONCLUSION}

The goal of this Article is to demonstrate the counterintuitive effect that a consistent approach to the propertization of IP has on related sanctions. We have argued that the rhetorical move of using the concept of property to increase sanctions and deploy harsher enforcement techniques stands in contrast to the actual structure of our system of property sanctions. In short, we often punish intellectual property violations with greater vigor than we would equivalent property offenses. Should our realization enter the legal mainstream, we predict a decrease in property language on the part of intellectual property owners because the instrumental value of that rhetoric would decrease if the goal of the speakers is simply broader and deeper protection. In the end, we agree with those who say that there are significant commonalities between property and intellectual property. Unlike many of the other advocates of that view, however, we are not invested in a particular outcome when it comes to sanctions. Rather, our goal is the promotion of productivity and free enterprise. Establishing optimal sanctions for property, intellectual property, or other legal regimes ultimately requires a more fine-grained analysis than that with which general labels can ever provide us. 


\section{APPENDICES}

\section{APPENDIX 1: VALUE OF THEFT/DAMAGE $\$ 1,000.01$ TO $\$ 2,500.00$ (STATUTE IN \\ PARENTHESES) $)^{138}$}

\begin{tabular}{|c|c|c|c|c|c|c|}
\hline State & $\begin{array}{c}\text { Theft Value } \\
\$ 1,000.01 \text { or } \\
\text { more }\end{array}$ & $\begin{array}{c}\text { Theft } \\
\text { Penalty }{ }^{139}\end{array}$ & $\begin{array}{c}\text { Vandalism } \\
\text { Value } \\
\$ 1,000.01 \text { or } \\
\text { more }\end{array}$ & $\begin{array}{c}\text { Vandalism } \\
\text { Penalty }\end{array}$ & $\begin{array}{c}\text { Trespass Value }{ }^{140} \\
\begin{array}{c}\$ 1,000.01 \\
\text { or }\end{array} \\
\text { more }\end{array}$ & Trespass Penalty \\
\hline $\begin{array}{c}\text { Alabama } \\
\text { (Ala. Code) }\end{array}$ & $\begin{array}{c}\$ 500-\$ 2,500 \\
(\$ 13 \mathrm{~A}-8-3)\end{array}$ & $\begin{array}{c}10 \text { years, } \\
\$ 15,000 \\
(\$ 13 \mathrm{~A}-5-6) \\
(\$ 13 \mathrm{~A}-5-11)\end{array}$ & $\$ \$ 500-\$ 2,500$ & $\begin{array}{c}1 \text { year, } \\
\$ 6,000 \\
(\$ 13 \mathrm{~A}-5-7) \\
(\$ 13-5-12) \\
\end{array}$ & $\overline{~(\$ 13 A-7-2)}$ & $\begin{array}{c}1 \text { year, } \$ 6,000 \\
(\$ 13 \mathrm{~A}-5-7) \\
(\$ 13-5-12)\end{array}$ \\
\hline Alaska (AS) & $\begin{array}{c}\$ 750-\$ 25,000 \\
(\$ 11.46 .130)\end{array}$ & $\begin{array}{c}5 \text { years, } \\
\$ 50,000 \\
(\$ 12.55 .15) \\
(\$ 12.55 .035)\end{array}$ & $\begin{array}{c}\text { More than } \\
\$ 750 \\
(\$ 11.46 .482)\end{array}$ & $\begin{array}{c}5 \text { years, } \\
\$ 50,000 \\
(\$ 12.55 .125) \\
(\$ 12.55 .035)\end{array}$ & $(\$ 11.46 .320)$ & $\begin{array}{c}1 \text { year, } \$ 10,000 \\
(\$ 12.55 .135) \\
(\$ 12.55 .035)\end{array}$ \\
\hline $\begin{array}{l}\text { Arizona } \\
\text { (A.R.S.) }\end{array}$ & $\begin{array}{c}\$ 1,000- \\
\$ 1,999 \\
(\$ 13-1802)\end{array}$ & $\begin{array}{l}1.5 \text { years, } \\
\$ 150,000 \\
(\$ 13-702) \\
(\$ 13-801)\end{array}$ & $\begin{array}{c}\text { Less than } \\
\$ 1,500 \\
(\$ 13-1604)\end{array}$ & $\begin{array}{l}1.5 \text { years, } \\
\$ 150,000 \\
(\$ 13-702) \\
(\$ 13-801)\end{array}$ & $(\$ 13-1504)$ & $\begin{array}{c}1.5 \text { years, } \\
\$ 150,000 \\
(\$ 13-702) \\
(\$ 13-801) \\
\text { or } 6 \text { months, } \\
\$ 2,500 \\
(\$ 13-707) \\
(\$ 13-802)\end{array}$ \\
\hline $\begin{array}{l}\text { Arkansas } \\
\text { (A.C.A.) }\end{array}$ & $\begin{array}{c}\$ 1,000.01- \\
\$ 4,999 \\
(\$ 5-36-103)\end{array}$ & $\begin{array}{c}6 \text { years, } \\
\$ 10,000 \\
(\$ 5-4-401) \\
(\$ 5-4-201) \\
\end{array}$ & $\begin{array}{c}\$ 1,000.01- \\
\$ 5,000 \\
(\$ 5-38-203)\end{array}$ & $\begin{array}{c}6 \text { years, } \\
\$ 10,000 \\
(\$ 5-4-401) \\
(\$ 5-4-201) \\
\end{array}$ & $(\S 5-39-203)$ & $\begin{array}{c}90 \text { days, } \$ 1,000 \\
(\$ 5-4-401)\end{array}$ \\
\hline $\begin{array}{l}\text { California } \\
\text { (Cal. Pen. } \\
\text { Code) }\end{array}$ & $\begin{array}{c}\$ 950 \text { or more } \\
(\$ 487)\end{array}$ & $\begin{array}{l}1 \text { year, } \\
\$ 5,000 \\
(\$ 489)\end{array}$ & $\begin{array}{c}\$ 400 \text { or more } \\
(\$ 594)\end{array}$ & $\begin{array}{l}1 \text { year, } \\
\$ 10,000 \\
(\$ 594)\end{array}$ & $(\S 601)$ & $\begin{array}{c}1 \text { year, } \$ 2,000 \\
(\$ 601)\end{array}$ \\
\hline $\begin{array}{l}\text { Colorado } \\
\text { (C.R.S.A.) }\end{array}$ & $\begin{array}{l}\$ 750-\$ 1,999 \\
(\$ 18-4-401)\end{array}$ & $\begin{array}{c}1 \text { year, } \\
\$ 1,000 \\
(\$ 18-1.3-505)\end{array}$ & $\begin{array}{c}\$ 1,000- \\
\$ 4,999 \\
(\$ 18-4-501) \\
\end{array}$ & $\begin{array}{c}18 \text { months, } \\
\$ 100,000 \\
(\$ 18-1.3-401) \\
\end{array}$ & $(\S 18-4-502)$ & $\begin{array}{c}3 \text { years, } \$ 100,000 \\
(\$ 18-1.3-401)\end{array}$ \\
\hline
\end{tabular}

138. Each state's relevant statutes are listed in parentheses. Several states list penalties separately from the crimes themselves, which is why several penalty provisions may be listed. See, e.g., Alabama's Theft Penalty, Ala. Code $§ 13$ A-8-3.

139. All penalties state maximum prison or jail sentences and maximum fines.

140. The majority of trespass statutes do not specify an amount of damage. In those instances, the statute for criminal trespass is simply cited. 
Winter 2015]

IP AS VANDALISM

355

\begin{tabular}{|c|c|c|c|c|c|c|}
\hline $\begin{array}{l}\text { Connecticut } \\
\text { (C.G.S.A.) }\end{array}$ & $\begin{array}{c}\$ 1,000 \text { or } \\
\text { more } \\
(\$ 53 a-125)\end{array}$ & $\begin{array}{c}1 \text { year, } \\
\$ 2,000 \\
(\$ 53 \mathrm{a}-26) \\
(\$ 53 \mathrm{a}-42)\end{array}$ & $\begin{array}{c}\$ 250.01- \\
\$ 1,500(\$ 53 a- \\
116)\end{array}$ & $\begin{array}{c}1 \text { year, } \\
\$ 2,000 \\
(\$ 53 \mathrm{a}-26) \\
(\$ 53 \mathrm{a}-42)\end{array}$ & $(\$ 53 a-107)$ & $\begin{array}{c}\text { year, } \$ 2,000 \\
(\$ 53 \mathrm{a}-26) \\
(\$ 33 \mathrm{a}-42)\end{array}$ \\
\hline $\begin{array}{c}\text { Delaware } \\
\text { (11 Del. C.) }\end{array}$ & $\begin{array}{l}\text { Less than } \\
\$ 1,500 \\
(\$ 841)\end{array}$ & $\begin{array}{l}1 \text { year, } \\
\$ 2,300 \\
(\$ 4206)\end{array}$ & $\begin{array}{l}\text { More than } \\
\$ 1,000(\$ 811)\end{array}$ & $\begin{array}{l}1 \text { year, } \\
\$ 2,300 \\
(\$ 4206)\end{array}$ & $(\S 823)$ & $\begin{array}{c}1 \text { year, } \$ 2,300 \\
(\S 4206)\end{array}$ \\
\hline $\begin{array}{c}\text { District of } \\
\text { Columbia } \\
\text { (DC ST) }\end{array}$ & $\begin{array}{l}\$ 1,000 \text { or } \\
\text { more } \\
(\$ 22-3212)\end{array}$ & $\begin{array}{c}10 \text { years, } \\
\$ 25,000 \\
(\$ 22-3212) \\
(\$ 22- \\
3571.01)\end{array}$ & $(\S 22-312.01)$ & $\begin{array}{c}180 \text { days, at } \\
\text { least } \$ 250 \text {, } \\
\$ 1,000 \max \\
(\$ 22- \\
3312.04) \\
(\$ 22- \\
3571.01)\end{array}$ & $(\$ 22-3301)$ & $\begin{array}{c}\text { year, } \$ 2,500 \\
(\$ 22-3301) \\
(\$ 22-3571.01)\end{array}$ \\
\hline $\begin{array}{l}\text { Florida } \\
\text { (F.S.A.) }\end{array}$ & $\begin{array}{c}\$ 300-\$ 4,999 \\
(\$ 812.014)\end{array}$ & $\begin{array}{c}5 \text { years, } \\
\$ 5,000 \\
(\$ 775.082) \\
(\$ 775.08)\end{array}$ & $\begin{array}{c}\$ 1,000.01 \text { or } \\
\text { more } \\
(\$ 806.13)\end{array}$ & $\begin{array}{c}5 \text { years, } \\
\$ 5,000 \\
(\$ 775.082) \\
(\$ 860.13) \\
(\$ 775.083)\end{array}$ & $(\$ 810.09)$ & $\begin{array}{c}1 \text { year, } \$ 1,000 \\
(\$ 775.082) \\
(\$ 775.083)\end{array}$ \\
\hline $\begin{array}{l}\text { Georgia } \\
\text { (Ga. Code } \\
\text { Ann.) }\end{array}$ & $\begin{array}{c}\$ 1,500 \text { or less } \\
(\$ 16-8-12)\end{array}$ & $\begin{array}{c}1 \text { year, } \\
\$ 1,000(\S 17- \\
10-3)\end{array}$ & $\begin{array}{l}\text { More than } \\
\$ 500 \\
(\S 16-7-23)\end{array}$ & $\begin{array}{c}5 \text { years } \\
(\S 16-7-22)\end{array}$ & $\begin{array}{c}\$ 500 \text { or less } \\
(\$ 16-7-21)\end{array}$ & $\begin{array}{c}12 \text { months, } \\
\$ 1,000 \text { (\$17-10- } \\
3)\end{array}$ \\
\hline $\begin{array}{l}\text { Hawaii } \\
\text { (HRS) }\end{array}$ & $\begin{array}{c}\$ 300.01 \\
(\$ 708-831)\end{array}$ & $\begin{array}{c}5 \text { years, } \\
\$ 10,000+ \\
\$ 1,000 \text { min } \\
(\$ 706-660 ; \\
\$ 706-640) \\
(\$ 708-831)\end{array}$ & $\begin{array}{c}\$ 500.01 \\
(\$ 708-822)\end{array}$ & $\begin{array}{c}\$ 2,000 \\
(\$ 706-663) \\
(\$ 706-640)\end{array}$ & $(\$ 708-813)$ & $\begin{array}{c}1 \text { year, } \$ 2,000 \\
(\$ 706-663) \\
(\$ 706-640)\end{array}$ \\
\hline $\begin{array}{l}\text { Idaho } \\
\text { (I.C.) }\end{array}$ & $\begin{array}{c}\$ 1,000.01 \text { or } \\
\text { more } \\
(\S 18-2407)\end{array}$ & $\begin{array}{c}20 \text { years, } \\
\$ 10,000 \\
(\$ 18-2408) \\
\end{array}$ & $\begin{array}{c}\$ 1,000.01 \text { or } \\
\text { more } \\
(\S 18-7001)\end{array}$ & $\begin{array}{c}1 \text { year, } \\
\$ 1,000 \\
(\$ 08-7001)\end{array}$ & (§18-7011) & $\begin{array}{c}6 \text { months, } \$ 1,000 \\
(\S 18-7011)\end{array}$ \\
\hline $\begin{array}{l}\text { Illinois } \\
\text { (ILCS) }\end{array}$ & $\begin{array}{c}\$ 500.01- \\
\$ 10,000 \\
(720 \text { ILCS } \\
5 / 16-1)\end{array}$ & $\begin{array}{c}5 \text { years, } \\
\$ 25,000(720 \\
\text { ILCS } 5 / 5-7.5- \\
40) \\
(720 \text { ILCS } \\
5 / 5-4.5-50) \\
\end{array}$ & $\begin{array}{c}\$ 300.01- \\
\$ 10,000 \\
(720 \text { ILCS } \\
5 / 21-1)\end{array}$ & $\begin{array}{c}3 \text { years, } \\
\$ 25,000 \\
(720 \text { ILCS } \\
5 / 5-7.5-45) \\
(720 \text { ILCS } \\
5 / 5-4.5-50)\end{array}$ & $\begin{array}{c}\text { (720 ILCS } \\
5 / 21-3)\end{array}$ & $\begin{array}{c}1 \text { year, } \$ 2,500 \\
\text { (720 ILCS 5/5- } \\
4.5-55)\end{array}$ \\
\hline $\begin{array}{l}\text { Indiana } \\
\text { (IC) }\end{array}$ & $\begin{array}{c}\$ 750-\$ 49,999 \\
(\$ 35-43-4-2)\end{array}$ & $\begin{array}{c}3 \text { years, } \\
\$ 10,000 \\
(\$ 35-50-2-7)\end{array}$ & $\begin{array}{c}\$ 750-\$ 49,999 \\
(\$ 35-43-1-2)\end{array}$ & $\begin{array}{c}1 \text { year, } \\
\$ 5,000 \\
(\$ 35-50-3-2)\end{array}$ & $\begin{array}{c}\$ 750-\$ 49,999 \\
(\$ 35-43-2-2)\end{array}$ & $\begin{array}{c}3 \text { years, } \$ 10,000 \\
(\$ 35-50-2-7)\end{array}$ \\
\hline $\begin{array}{c}\text { Iowa } \\
\text { (I.C.A.) }\end{array}$ & $\begin{array}{l}\$ 1,000.01- \\
\$ 10,000 \\
(\$ 714.2)\end{array}$ & $\begin{array}{l}5 \text { years, } \\
\$ 7,500 \\
(\$ 902.9) \\
\end{array}$ & $\begin{array}{c}\$ 1,000.01- \\
\$ 10,000 \\
(\$ 716.4)\end{array}$ & $\begin{array}{l}5 \text { years, } \\
\$ 7,500 \\
(\$ 902.9) \\
\end{array}$ & $\begin{array}{c}\$ 200.01 \text { or more } \\
(\$ 716.8)\end{array}$ & $\begin{array}{c}1 \text { year, } \$ 1,875 \\
(\S 903.1)\end{array}$ \\
\hline
\end{tabular}


[Vol. 18:331

\begin{tabular}{|c|c|c|c|c|c|c|}
\hline $\begin{array}{l}\text { Kansas } \\
\text { (K.S.A.) }\end{array}$ & $\begin{array}{c}\$ 1,000- \\
\$ 24,999 \\
(\$ 21-5801)\end{array}$ & $\begin{array}{l}7 \text { months, } \\
\$ 100,000 \\
(\$ 21-6611) \\
(\S 21-6804) \\
\end{array}$ & $\begin{array}{c}\$ 1,000- \\
\$ 24,999 \\
(\$ 21-5813)\end{array}$ & $\begin{array}{c}\$ 100,000 \\
(\$ 21-6611) \\
(\$ 21-6804)\end{array}$ & $(\S 21-5808)$ & $\begin{array}{c}6 \text { months, } \$ 1,000 \\
(\$ 21-6602) \\
(\$ 21-6611)\end{array}$ \\
\hline $\begin{array}{l}\text { Kentucky } \\
\text { (KRS) }\end{array}$ & $\begin{array}{c}\$ 500-\$ 9,999 \\
(\$ 514.030)\end{array}$ & $\begin{array}{c}5 \text { years, } \\
\$ 10,000 \\
(\$ 532.020) \\
(\$ 534.0) \\
\end{array}$ & $\begin{array}{l}\$ 1,000 \text { or } \\
\text { more } \\
(\$ 512.020)\end{array}$ & $\begin{array}{c}5 \text { years, } \\
\$ 10,000 \\
(\$ 532.020) \\
(\$ 534.030) \\
\end{array}$ & $(\S 511.060)$ & $\begin{array}{l}1 \text { year, } \$ 500 \\
(\$ 532.020) \\
(\$ 534.040)\end{array}$ \\
\hline $\begin{array}{l}\text { Louisiana } \\
\text { (LSA-RS) }\end{array}$ & $\begin{array}{c}\$ 500-\$ 1,499 \\
(\mathrm{LSA}- \\
\text { R.S.\$67) }\end{array}$ & $\begin{array}{c}10 \text { years, } \\
\$ 3,000 \text { (LSA- } \\
\text { R.S. } \$ 67)\end{array}$ & $\begin{array}{c}\text { Simple } \\
\text { criminal } \\
\text { damage at } \\
\text { property } \\
\$ 500- \\
\$ 49,999(\mathrm{LSA} \\
\text {-R.S. } \$ 14: 56) \\
\end{array}$ & $\begin{array}{c}2 \text { years, } \\
\$ 1,000 \\
(\text { LSA-R.S. } \\
\$ 14-56)\end{array}$ & (LSA-R.S. §63) & $\begin{array}{c}30 \text { days, } \$ 500 \\
\text { (LSA-R.S. } \$ 63 \text { ) }\end{array}$ \\
\hline $\begin{array}{c}\text { Maine } \\
\text { (Title } 32 \\
\text { M.R.S.A.) }\end{array}$ & $\begin{array}{c}\$ 1,000.01- \\
\$ 10,000 \\
(\$ 353)\end{array}$ & $\begin{array}{l}5 \text { years, } \\
\$ 5,000 \\
(\$ 1252) \\
(\$ 1301)\end{array}$ & $(\S 806)$ & $\begin{array}{l}1 \text { year, } \\
\$ 2,000 \\
(\$ 1252) \\
(\$ 1301)\end{array}$ & $(\S 402)$ & $\begin{array}{c}1 \text { year, } \$ 2,000 \\
(\$ 1252) \\
(\$ 1301)\end{array}$ \\
\hline $\begin{array}{c}\text { Maryland } \\
\text { (MD Code, } \\
\text { Criminal Law) } \\
\end{array}$ & $\begin{array}{c}\$ 1,000- \\
\$ 9,999 \\
(\$ 7-104)\end{array}$ & $\begin{array}{l}10 \text { years, } \\
\$ 10,000 \\
(\$ 7-104)\end{array}$ & $\begin{array}{c}\$ 1,000 \text { or } \\
\text { more } \\
(\$ 6-301)\end{array}$ & $\begin{array}{l}3 \text { years, } \\
\$ 2,500 \\
(\$ 6-301)\end{array}$ & $(\S 6-402)$ & $\begin{array}{c}90 \text { days, } \\
\$ 500(\$ 6-402)\end{array}$ \\
\hline $\begin{array}{l}\text { Massachusetts } \\
\text { (M.G.L.A.) }\end{array}$ & $\begin{array}{l}\text { More than } \\
\$ 250 \\
(266 \$ 30)\end{array}$ & $\begin{array}{c}5 \text { years OR } 2 \\
\text { years, } \\
\$ 25,000 \\
(266 \S 30)\end{array}$ & $(266 \S 127)$ & $\begin{array}{c}\text { Greater of } \\
\$ 1,500 \text { or } 3 x \\
\text { value OR } 2.5 \\
\text { years } \\
(266 \S 127) \\
\end{array}$ & $(266 \S 120)$ & $\begin{array}{c}30 \text { days, } \$ 100 \\
(266 \$ 120)\end{array}$ \\
\hline $\begin{array}{l}\text { Michigan } \\
\text { (M.C.L.A.) }\end{array}$ & $\begin{array}{c}\$ 1,000- \\
\$ 19,999 \\
(\$ 750.356)\end{array}$ & $\begin{array}{c}5 \text { years, } \\
\text { greater of } \\
\$ 10,000 \text { or } 3 \mathrm{x} \\
\text { value } \\
(\$ 750.356)\end{array}$ & $\begin{array}{c}\$ 1,000- \\
\$ 19,999 \\
(\$ 750.377 a)\end{array}$ & $\begin{array}{c}5 \text { years, } \\
\text { greater of } \\
\$ 10,000 \text { or } 3 x \\
\text { value } \\
(\$ 750.377 a)\end{array}$ & $(\S 750.552)$ & $\begin{array}{c}30 \text { days, } \$ 250 \\
(\$ 750.552)\end{array}$ \\
\hline $\begin{array}{l}\text { Minnesota } \\
\text { (M.S.A.) }\end{array}$ & $\begin{array}{c}\$ 1,000.01- \\
\$ 4,999 \\
(\$ 609.52) \\
\end{array}$ & $\begin{array}{l}5 \text { years, } \\
\$ 10,000 \\
(\$ 609.52) \\
\end{array}$ & $\begin{array}{l}\text { More than } \\
\$ 1,000 \\
(\$ 609.595) \\
\end{array}$ & $\begin{array}{c}5 \text { years, } \\
\$ 10,000 \\
(\$ 609.595) \\
\end{array}$ & $(\S 609.605)$ & $\begin{array}{c}90 \text { days, } \$ 1,000 \\
(\$ 609.03)\end{array}$ \\
\hline $\begin{array}{l}\text { Mississippi } \\
\text { (Miss. Code } \\
\text { Ann.) }\end{array}$ & $\begin{array}{c}\$ 1,000- \\
\$ 4,999 \\
(\$ 97-17-41) \\
\end{array}$ & $\begin{array}{c}5 \text { years, } \\
\$ 10,000 \\
(\$ 97-17-41) \\
\end{array}$ & $\begin{array}{c}\$ 1,000.01- \\
\$ 4,999 \\
(\$ 97-17-67) \\
\end{array}$ & $\begin{array}{c}5 \text { years, } \\
\$ 10,000 \\
(\$ 97-17-67) \\
\end{array}$ & $(\S 97-17-87)$ & $\begin{array}{l}6 \text { months, } \$ 500 \\
(\S 97-17-87)\end{array}$ \\
\hline $\begin{array}{l}\text { Missouri } \\
\text { (RSMo) }\end{array}$ & $\begin{array}{c}\$ 500-\$ 24,999 \\
(\$ 570.030)\end{array}$ & $\begin{array}{c}7 \text { years, } \\
\text { greater of } \\
\$ 5,000 \text { or } 2 \mathrm{x} \\
\text { value } \\
(\$ 570.030) \\
(\$ 558.011) \\
(\$ 560.011)\end{array}$ & $\begin{array}{l}\text { More than } \\
\$ 750 \\
(\$ 569.100)\end{array}$ & $\begin{array}{c}4 \text { years, } \\
\text { greater of } \\
\$ 5,000 \text { or } 2 x \\
\text { value } \\
(\$ 558.011) \\
(\$ 569.100) \\
(\$ 560.011)\end{array}$ & $(\$ 569.140)$ & $\begin{array}{c}6 \text { months, } \$ 500 \\
(\$ 558.011) \\
(\$ 560.016)\end{array}$ \\
\hline
\end{tabular}


Winter 2015]

\begin{tabular}{|c|c|c|c|c|c|c|}
\hline $\begin{array}{c}\text { Montana } \\
\text { (MCA) }\end{array}$ & $\begin{array}{c}\$ 1,500 \text { or less } \\
(\$ 45-6-301)\end{array}$ & $\begin{array}{c}6 \text { months, } \\
\$ 1,500 \\
\text { (§45-6-301) }\end{array}$ & \begin{tabular}{|c}
$\$ 1,500$ or less \\
$(\$ 45-6-101)$
\end{tabular} & $\begin{array}{c}6 \text { months, } \\
\$ 1,500 \\
(\S 45-6-101) \\
\end{array}$ & $(\$ 45-6-203)$ & $\begin{array}{c}6 \text { months, } \$ 500 \\
(\$ 45-6-203)\end{array}$ \\
\hline $\begin{array}{c}\text { Nebraska } \\
\text { (Neb.Rev.St.) }\end{array}$ & $\begin{array}{c}\$ 500-\$ 1,500 \\
(\$ 28-518)\end{array}$ & $\begin{array}{c}5 \text { years, } \\
\$ 10,000(\$ 28- \\
105)\end{array}$ & $\begin{array}{c}\$ 500-\$ 1,499 \\
(\$ 28-519)\end{array}$ & $\begin{array}{c}1 \text { year, } \\
\$ 1,000 \\
(\$ 28-106)\end{array}$ & $(\S 28-520)$ & $\begin{array}{c}1 \text { year, } \$ 1,000 \\
(\$ 28-106)\end{array}$ \\
\hline $\begin{array}{c}\text { Nevada } \\
(\text { N.R.S. })^{141}\end{array}$ & $\begin{array}{c}\$ 650.01- \\
\$ 3,499 \\
(\$ 205.222)\end{array}$ & $\begin{array}{c}5 \text { years, } \\
\$ 10,000 \\
(\$ 193.130)\end{array}$ & $\begin{array}{c}\$ 250-\$ 4,999 \\
(\$ 206.330)\end{array}$ & $\begin{array}{l}364 \text { days, } \\
\$ 2,000 \\
(\$ 193.140)\end{array}$ & $(\S 206.140)$ & $\begin{array}{c}\text { Value of damage, } \\
\text { at least } 6 \text { months, } \\
\$ 1,000 \\
(\$ 206.140) \\
(\$ 193.150)\end{array}$ \\
\hline $\begin{array}{c}\text { New } \\
\text { Hampshire } \\
\text { (N.H. Rev. } \\
\text { Stat) }\end{array}$ & $\begin{array}{c}\$ 1,000.01- \\
\$ 1,500 \\
(\$ 637: 11)\end{array}$ & $\begin{array}{l}7 \text { years, } \\
\$ 4,000 \\
(\$ 651: 2)\end{array}$ & $\begin{array}{c}\$ 100.01- \\
\$ 1,500 \\
(\$ 634: 2)\end{array}$ & $\begin{array}{l}1 \text { year, } \\
\$ 2,000 \\
(\$ 651: 2)\end{array}$ & $\begin{array}{c}\$ 1,500 \text { or less } \\
(\$ 635: 2)\end{array}$ & $\begin{array}{c}1 \text { year, } \$ 1,200 \\
(\$ 651: 2)\end{array}$ \\
\hline $\begin{array}{l}\text { New Jersey } \\
\text { (N.J.S.A.) }\end{array}$ & $\begin{array}{c}\$ 500.01- \\
\$ 74,999 \\
(\$ 2 \mathrm{C}: 20-2)\end{array}$ & $\begin{array}{c}5 \text { years, } \\
\$ 15,000 \\
(\$ 2 \mathrm{C}: 43-6 \\
(\$ 2 \mathrm{C}: 43-3) \\
\end{array}$ & $\begin{array}{c}\$ 500.01- \\
\$ 1,999 \\
(\$ 2 C: 17-3)\end{array}$ & $\begin{array}{l}18 \text { months, } \\
\$ 10,000 \\
(\$ 2 \mathrm{C}: 43-6) \\
(\S 2 \mathrm{C}: 43-3)\end{array}$ & (§2C:18-3) & $\begin{array}{c}18 \text { months, } \\
\$ 10,000 \text { (\$2C:43- } \\
6) \\
(\S 2 \mathrm{C}: 43-3)\end{array}$ \\
\hline $\begin{array}{c}\text { New Mexico } \\
\text { (N.M.S.A. } \\
\text { 1978) }\end{array}$ & $\begin{array}{c}\$ 500.01- \\
\$ 2,500 \\
(\$ 30-16-1)\end{array}$ & $\begin{array}{c}18 \text { months, } \\
\$ 5,000 \\
(\$ 31-18-15)\end{array}$ & $\begin{array}{c}\text { More than } \\
\$ 1,000 \\
(\$ 30-15-1)\end{array}$ & $\begin{array}{c}18 \text { months, } \\
\$ 5,000 \\
(\$ 31-18-15)\end{array}$ & $(\S 30-14-1.1)$ & $\begin{array}{c}\text { Double appraised } \\
\text { value of damage } \\
\text { (\$30-14-1.1) }\end{array}$ \\
\hline $\begin{array}{c}\text { New York } \\
\text { (McKinney's } \\
\text { Penal Law) }\end{array}$ & $\begin{array}{l}\text { More than } \\
\$ 1,000 \\
(\$ 155.30)\end{array}$ & \begin{tabular}{|c|}
4 years \\
$(\$ 70.00)$ (no \\
fine specified \\
$\S 80.00)$ \\
\end{tabular} & $\begin{array}{l}\text { More than } \\
\$ 250 \\
(\$ 145.05)\end{array}$ & \begin{tabular}{|c|}
4 years \\
$(\S 70.00)($ no \\
fine specified \\
$\S 80.00)$ \\
\end{tabular} & $(\S 140.15)$ & $\begin{array}{c}1 \text { year, } \$ 1,000 \\
(\$ 70.15) \\
(\$ 80.00)\end{array}$ \\
\hline $\begin{array}{l}\text { North Carolina } \\
\text { (N.C.G.S.A.) }\end{array}$ & $\begin{array}{l}\text { Larceny of } \\
\text { goods More } \\
\text { than } \$ 1,000 \\
(\$ 14-72)\end{array}$ & \begin{tabular}{|c}
8 years \\
$(\S 15 \mathrm{~A}-$ \\
$1340.17)$ \\
fines appear \\
to be \\
discretionary \\
(§15A-1361 \\
et seq.)
\end{tabular} & $\begin{array}{c}\text { Vandalism } \\
\text { statutes are } \\
\text { specific to } \\
\text { agriculture, } \\
\text { public } \\
\text { facilities, and } \\
\text { other unique } \\
\text { categories } \\
\text { (e.g. \$14-132) }\end{array}$ & $\begin{array}{c}6 \text { months, } \\
\$ 1,000 \\
(\S 14-3) \\
(\S 15 \mathrm{~A}- \\
1340.23)\end{array}$ & $\begin{array}{c}\text { More than } \\
\$ 200(\$ 14-160)\end{array}$ & $\begin{array}{c}1 \text { year, } \\
\text { discretionary fine } \\
(\$ 14-3) \\
(\$ 15 \mathrm{~A}-1340.23)\end{array}$ \\
\hline $\begin{array}{l}\text { North Dakota } \\
\text { (NDCC) }\end{array}$ & $\begin{array}{c}\$ 1,000.01 \text { or } \\
\text { more } \\
(\$ 12.1-23-05)\end{array}$ & $\begin{array}{c}5 \text { years, } \\
\$ 10,000 \\
(\$ 12.0-32-01)\end{array}$ & $\begin{array}{c}\$ 100-\$ 2,000 \\
\text { (reckless } \\
\text { damage More } \\
\text { than } \$ 2,500) \\
(\$ 12.1-21-05) \\
\end{array}$ & $\begin{array}{c}1 \text { year, } \\
\$ 3,000 \\
(\$ 12.1-32-01)\end{array}$ & $(\$ 12.1-22-03)$ & $\begin{array}{l}1 \text { year, } \$ 3,000 \\
(\S 12.1-32-01)\end{array}$ \\
\hline
\end{tabular}

141. Nevada has separate statutes for theft and larceny; larceny statutes are cited herein. 


\begin{tabular}{|c|c|c|c|c|c|c|}
\hline Ohio (R.C.) & $\begin{array}{c}\$ 1,000- \\
\$ 7,499 \\
(\$ 2913.02)\end{array}$ & $\begin{array}{c}1 \text { year, } \\
\$ 2,500 \\
(\$ 2929.14) \\
(\$ 2929.18)\end{array}$ & $\begin{array}{l}\$ 1,000 \text { or } \\
\text { more } \\
(\$ 2909.05)\end{array}$ & $\begin{array}{c}1 \text { year, } \\
\$ 2,500 \\
(\$ 2929.14) \\
(\$ 2929.18) \\
(\$ 2905.05) \\
\end{array}$ & $(\S 2911.21)$ & $\begin{array}{c}30 \text { days, } \$ 250 \\
(\$ 2929.24) \\
(\$ 2929.28)\end{array}$ \\
\hline $\begin{array}{c}\text { Oklahoma } \\
\quad(21 \\
\text { Okl.Stat.Ann) }\end{array}$ & $\begin{array}{c}\$ 500 \text { or more } \\
(\$ 1705)\end{array}$ & $\begin{array}{c}5 \text { years, } \\
\$ 5,000 \\
(\$ 1705)\end{array}$ & $\begin{array}{c}\$ 1,000 \text { or } \\
\text { more } \\
(\$ 1760)\end{array}$ & $\begin{array}{c}2 \text { years, } \\
\$ 1,000 \\
(\$ 9)\end{array}$ & $(§ 1835)$ & $\begin{array}{c}30 \text { days, } \$ 500 \\
(\$ 1835)\end{array}$ \\
\hline $\begin{array}{l}\text { Oregon } \\
\text { (O.R.S.) }\end{array}$ & $\begin{array}{c}\$ 1000 \text { or } \\
\text { more } \\
(\$ 164.055)\end{array}$ & $\begin{array}{c}5 \text { years, } \\
\$ 125,000 \\
(\$ 161.605) \\
(\$ 161.625) \\
\end{array}$ & $\begin{array}{c}\$ 1000.01 \text { or } \\
\text { more } \\
(\$ 164.365)\end{array}$ & $\begin{array}{c}5 \text { years, } \\
\$ 125,000 \\
(\$ 161.605) \\
(\$ 161.625) \\
\end{array}$ & $(\S 164.255)$ & $\begin{array}{c}1 \text { year, } \$ 6250 \\
(\$ 161.615) \\
(\$ 161.635)\end{array}$ \\
\hline $\begin{array}{c}\text { Pennsylvania } \\
\text { (Pa.C.S.A.) }\end{array}$ & $\begin{array}{c}\$ 50-\$ 1999.99 \\
(\$ 3903)\end{array}$ & $\begin{array}{l}5 \text { years, } \\
\$ 10,000 \\
(\$ 1103) \\
(\$ 1101)\end{array}$ & $\begin{array}{c}\$ 1000.01- \\
\$ 5,000 \\
(\$ 3304)\end{array}$ & $\begin{array}{l}2 \text { years, } \\
\$ 5,000 \\
(\$ 1103) \\
(\$ 1101)\end{array}$ & $(\S 3503)$ & $\begin{array}{c}1 \text { year, } \$ 2,500 \\
(\$ 1103) \\
(\$ 1101)\end{array}$ \\
\hline $\begin{array}{c}\text { Rhode Island } \\
\text { (Gen. Laws) }\end{array}$ & $\begin{array}{c}\$ 1,500 \text { or less } \\
(\$ 11-41-5)\end{array}$ & $\begin{array}{l}1 \text { year, } \$ 500 \\
(\$ \$ 11-41-5)\end{array}$ & $(\S 11-44-1)$ & $\begin{array}{c}1 \text { year, } \\
\$ 1,000 \\
(\$ 11-44-1) \\
\end{array}$ & $(\S 11-44-26)$ & $\begin{array}{c}1 \text { year, } \$ 1,000 \\
(\$ 11-44-26)\end{array}$ \\
\hline $\begin{array}{l}\text { South Carolina } \\
\text { (Code })\end{array}$ & $\begin{array}{c}\$ 2,000 \text { or less } \\
(\$ 16-13-30)\end{array}$ & $\begin{array}{c}30 \text { days, } \\
\$ 1,000 \\
(\$ 16-13-30)\end{array}$ & $\begin{array}{c}\$ 2,000 \text { or less } \\
(\$ 16-11-520)\end{array}$ & $\begin{array}{c}30 \text { days, } \\
\$ 1,000 \\
(\$ 16-11-520)\end{array}$ & $(\S 16-11-600)$ & $\begin{array}{c}30 \text { days, } \$ 100 \\
(\$ 16-11-520)\end{array}$ \\
\hline $\begin{array}{l}\text { South Dakota } \\
\text { (SDCL) }\end{array}$ & $\begin{array}{c}\$ 1,000.01- \\
\$ 2,500 \\
(\$ 22-30 \mathrm{~A}-17)\end{array}$ & $\begin{array}{c}2 \text { years, } \\
\$ 4,000 \\
(\$ 22-6-1)\end{array}$ & $\begin{array}{c}\$ 1,000.01- \\
\$ 2,500 \\
(\$ 22-34-11)\end{array}$ & $\begin{array}{c}2 \text { years, } \\
\$ 4,000 \\
(\$ 22-6-1)\end{array}$ & $(\S 22-35-5)$ & $\begin{array}{c}1 \text { year, } \$ 2,000 \\
(\$ 22-6-2)\end{array}$ \\
\hline $\begin{array}{c}\text { Tennessee } \\
\text { (T.C.A.) }\end{array}$ & $\begin{array}{c}\$ 1,000- \\
\$ 9,999 \\
(\$ 39-14-105)\end{array}$ & $\begin{array}{c}12 \text { years, } \\
\$ 5,000(\$ 40- \\
35-111)\end{array}$ & $\begin{array}{c}\$ 1,000- \\
\$ 9,999 \\
(\$ 39-14-105)\end{array}$ & $\begin{array}{c}12 \text { years, } \\
\$ 5,000 \\
(\$ 40-35-111)\end{array}$ & $(\$ 39-14-406)$ & $\begin{array}{c}6 \text { months, } \$ 500 \\
(\$ 40-35-111)\end{array}$ \\
\hline $\begin{array}{c}\text { Texas } \\
\text { (V.T.C.A.) }\end{array}$ & $\begin{array}{c}\$ 500-\$ 1,499 \\
(\$ 31.03)\end{array}$ & $\begin{array}{c}1 \text { year, } \\
\$ 4,000 \\
(\$ 12.21)\end{array}$ & $\begin{array}{c}\$ 500-\$ 1,499 \\
(\$ 28.03)\end{array}$ & $\begin{array}{c}1 \text { year, } \\
\$ 4,000 \\
(\$ 12.21)\end{array}$ & $(\S 30.05)$ & $\begin{array}{c}1 \text { year, } \$ 4,000 \\
(\$ 12.21)\end{array}$ \\
\hline $\begin{array}{c}\text { Utah } \\
\text { (U.C.A.) }\end{array}$ & $\begin{array}{c}\$ 500-\$ 1,499 \\
(\$ 76-6-412)\end{array}$ & $\begin{array}{c}1 \text { year, } \\
\$ 2,500(\$ 76- \\
3-204) \\
(\$ 76-3-301) \\
\end{array}$ & $\begin{array}{c}\$ 500-\$ 1,499 \\
(\$ 76-6-106)\end{array}$ & $\begin{array}{c}1 \text { year, } \\
\$ 2,500 \\
(\$ 76-3-204) \\
(\$ 76-3-301)\end{array}$ & $(\S 76-6-206)$ & $\begin{array}{c}1 \text { year, } \$ 2,500 \\
(\$ 76-3-204) \\
(\$ 76-3-301)\end{array}$ \\
\hline $\begin{array}{l}\text { Vermont } \\
\text { (V.S.A.) }\end{array}$ & $\begin{array}{l}\$ 900.01 \text { or } \\
\text { more } \\
(\$ 2501)\end{array}$ & $\begin{array}{c}10 \text { years, } \\
\$ 5,000 \\
(\$ 2501)\end{array}$ & $\begin{array}{c}\text { More than } \\
\$ 1,000 \\
(\$ 3701)\end{array}$ & $\begin{array}{c}5 \text { years, } \\
\$ 5,000 \\
(\$ 3701)\end{array}$ & $(\S 3705)$ & $\begin{array}{c}3 \text { years, } \$ 2,000 \\
(\$ 3705)\end{array}$ \\
\hline $\begin{array}{c}\text { Virginia } \\
\text { (VA Code } \\
\text { Ann.) }\end{array}$ & $\begin{array}{l}\$ 5 \text { or more } \\
\text { from the } \\
\text { person, } \$ 200 \\
\text { or more not } \\
\text { from the } \\
\text { person } \\
(\$ 18.2-95)\end{array}$ & $\begin{array}{c}20 \text { years, } \\
\$ 2,500 \\
(\$ 18.2-95)\end{array}$ & $\begin{array}{c}\$ 1,000 \text { or } \\
\text { more } \\
(\$ 18.2-137)\end{array}$ & $\begin{array}{c}5 \text { years, OR } 2 \\
\text { years and } \\
\$ 2,500 \\
(\$ 18.2-10)\end{array}$ & $(\S 18.2-121)$ & $\begin{array}{c}1 \text { year, } \$ 2,500 \\
(\$ 18.2-11)\end{array}$ \\
\hline
\end{tabular}


Winter 2015]

IP AS VANDALISM

359

\begin{tabular}{|c|c|c|c|c|c|c|}
\hline $\begin{array}{l}\text { Washington } \\
\text { (RCWA) }\end{array}$ & $\begin{array}{c}\$ 750.01- \\
\$ 5,000 \\
(\$ 9 \mathrm{~A} .56 .030)\end{array}$ & $\begin{array}{c}5 \text { years, } \\
\$ 10,000 \\
\text { (\$9A.20.020) }\end{array}$ & $\begin{array}{l}\$ 750 \text { or more } \\
\text { (\$9A.48.080) }\end{array}$ & $\begin{array}{c}5 \text { years, } \\
\$ 10,000 \\
(\$ 9 \mathrm{a} .20 .021)\end{array}$ & (§9A.52.070) & $\begin{array}{c}364 \text { days, } \$ 5,000 \\
(\$ 9.92 .020)\end{array}$ \\
\hline $\begin{array}{l}\text { West Virginia } \\
\text { (W.Va. Code) }\end{array}$ & $\begin{array}{c}\$ 1,000 \text { or } \\
\text { more } \\
(\S 61-3-13)\end{array}$ & $\begin{array}{c}10 \text { years, } \\
\$ 2,500 \\
(\$ 61-3-13)\end{array}$ & $\begin{array}{c}\text { Less than } \\
\$ 2,500 \\
(\S 61-3-30)\end{array}$ & $\begin{array}{c}1 \text { year, } \$ 500 \\
(\$ 61-3-30)\end{array}$ & $\begin{array}{c}\text { Knowing }(\S 61- \\
\text { 3B-2) }\end{array}$ & $\begin{array}{c}\$ 100 \\
(\$ 61-3 \mathrm{~B}-2)\end{array}$ \\
\hline $\begin{array}{l}\text { Wisconsin } \\
\text { (W.S.A.) }\end{array}$ & $\begin{array}{c}\$ 2,500 \text { or less } \\
(\$ 943.20)\end{array}$ & $\begin{array}{l}9 \text { months, } \\
\$ 10,000 \\
(\$ 939.51)\end{array}$ & $\begin{array}{c}\text { Less than } \\
\$ 2,500 \\
(\$ 943.01)\end{array}$ & $\begin{array}{c}9 \\
\text { months, } \\
\$ 10,000 \\
(\$ 939.51)\end{array}$ & $(\S 943.13)$ & $\begin{array}{l}9 \text { months, } \\
\$ 10,000 \\
(\$ 939.51)\end{array}$ \\
\hline $\begin{array}{l}\text { Wyoming } \\
\text { (W.S.) }\end{array}$ & $\begin{array}{c}\$ 1,000 \text { or } \\
\text { more } \\
(\S 6-3-402)\end{array}$ & $\begin{array}{c}10 \text { years, } \\
\$ 10,000 \\
(\$ 6-3-402)\end{array}$ & $\begin{array}{c}\$ 1,000 \text { or } \\
\text { more } \\
(\$ 6-3-201)\end{array}$ & $\begin{array}{c}10 \text { years, } \\
\$ 10,000 \\
(\$ 6-3-201)\end{array}$ & $(\$ 6-3-303)$ & $\begin{array}{c}6 \text { months, } \$ 750 \\
(\$ 6-3-303)\end{array}$ \\
\hline
\end{tabular}




\section{APPENDIX 2: VALUE OF THEFT/DAMAge \$2,500.01 OR MoRe (STATUTE IN PARENTHESES)}

\begin{tabular}{|c|c|c|c|c|c|c|}
\hline State & $\begin{array}{c}\text { Theft Value } \\
\$ 2,500.01 \text { or } \\
\text { more }\end{array}$ & $\begin{array}{c}\text { Theft } \\
\text { Penalty }\end{array}$ & $\begin{array}{l}\text { Vandalism } \\
\text { Value } \\
\$ 2,500.01 \text { or } \\
\text { more }\end{array}$ & $\begin{array}{c}\text { Vandalism } \\
\text { Penalty }\end{array}$ & $\begin{array}{c}\text { Trespass } \\
\text { Value } \\
\$ \mathbf{2 , 5 0 0 . 0 1} \text { or } \\
\text { more }\end{array}$ & $\begin{array}{l}\text { Trespass } \\
\text { Penalty }\end{array}$ \\
\hline $\begin{array}{c}\text { Alabama } \\
\text { (Ala. Code) }\end{array}$ & $\begin{array}{c}\$ 2500.01 \text { or } \\
\text { more } \\
(\$ 13 \mathrm{~A}-8-4)\end{array}$ & $\begin{array}{c}20 \text { years, } \\
\$ 30,000 \\
(\$ 13 \mathrm{~A}-5-6) \\
(\$ 13 \mathrm{~A}-5-11)\end{array}$ & $\begin{array}{c}\text { More than } \\
\$ 2500 \\
(\$ 13 \mathrm{~A}-7-21)\end{array}$ & $\begin{array}{c}10 \text { years, } \\
\$ 15,000 \\
(\$ 13 \mathrm{~A}-5-6) \\
(\$ 13 \mathrm{~A}-5-11)\end{array}$ & $(\$ 13 \mathrm{~A}-7-2)$ & $\begin{array}{c}1 \text { year, } \$ 6000 \\
(\$ 13 \mathrm{~A}-5-7) \\
(\S 13-5-12)\end{array}$ \\
\hline Alaska (AS) & $\begin{array}{c}\$ 750-\$ 25,000 \\
(\$ 11.46 .130)\end{array}$ & $\begin{array}{c}5 \text { years, } \\
\$ 50,000 \\
(\$ 12.55 .15) \\
(\$ 12.55 .035)\end{array}$ & $\begin{array}{c}\text { More than } \\
\$ 750 \\
(\$ 11.46 .482)\end{array}$ & $\begin{array}{c}5 \text { years, } \\
\$ 50,000 \\
(\$ 12.55 .125) \\
(\$ 12.55 .035) \\
\end{array}$ & $(\S 11.46 .320)$ & $\begin{array}{c}1 \text { year, } \$ 10,000 \\
(\S 12.55 .135) \\
(\$ 12.55 .035)\end{array}$ \\
\hline $\begin{array}{l}\text { Arizona } \\
\text { (A.R.S.) }\end{array}$ & $\begin{array}{c}\$ 2,000- \\
\$ 2,999 \\
(\$ 13-1802)\end{array}$ & $\begin{array}{c}2 \text { years, } \\
\$ 150,000 \\
(\$ 13-702) \\
(\$ 13-801)\end{array}$ & $\begin{array}{c}\$ 1,500-\$ 9,999 \\
(\$ 13-1604)\end{array}$ & $\begin{array}{c}2 \text { years, } \\
\$ 150,000(\S 13- \\
702) \\
(\$ 13-801)\end{array}$ & $(\S 13-1504)$ & $\begin{array}{c}1.5 \text { years, } \\
\$ 150,000(\S 13- \\
702) \\
(\$ 13-801) \\
\text { or } 6 \text { months, } \\
\$ 2,500 \\
(\$ 13-707)(\S 13- \\
802)\end{array}$ \\
\hline $\begin{array}{l}\text { Arkansas } \\
\text { (A.C.A.) }\end{array}$ & $\begin{array}{c}\$ 1,000.01- \\
\$ 4,999(\$ 5- \\
36-103)\end{array}$ & $\begin{array}{c}6 \text { years, } \\
\$ 10,000 \\
(\$ 5-4-401) \\
(\$ 5-4-201)\end{array}$ & $\begin{array}{c}\$ 1,000.01- \\
\$ 5,000 \\
(\$ 5-38-203)\end{array}$ & $\begin{array}{c}6 \text { years, } \\
\$ 10,000 \\
(\$ 5-4-401) \\
(\$ 5-4-201)\end{array}$ & $(\$ 5-39-203)$ & $\begin{array}{c}90 \text { days, } \$ 1,000 \\
(\S 5-4-401)(\S 5- \\
4-201)\end{array}$ \\
\hline $\begin{array}{c}\text { California } \\
\text { (Cal. Pen. } \\
\text { Code }) \\
\end{array}$ & $\begin{array}{c}\$ 950 \text { or more } \\
(\$ 487)\end{array}$ & $\begin{array}{c}1 \text { year, } \\
\$ 5,000(\$ 489)\end{array}$ & $\begin{array}{c}\$ 400 \text { or more } \\
(\$ 594)\end{array}$ & $\begin{array}{c}1 \text { year, } \\
\$ 10,000(\$ 594)\end{array}$ & $(\S 601)$ & $\begin{array}{c}1 \text { year, } \$ 2,000 \\
(\$ 601)\end{array}$ \\
\hline $\begin{array}{l}\text { Colorado } \\
\text { (C.R.S.A.) }\end{array}$ & $\begin{array}{c}\$ 2,000- \\
\$ 4,999 \\
(\$ 18-4-401) \\
\end{array}$ & $\begin{array}{c}18 \text { months, } \\
\$ 100,000 \\
(\$ 18-1.3-401) \\
\end{array}$ & $\begin{array}{c}\$ 1,000-\$ 4,999 \\
(\$ 18-4-501)\end{array}$ & $\begin{array}{c}18 \text { months, } \\
\$ 100,000 \\
(\$ 18-1.3-401) \\
\end{array}$ & $(\S 18-4-502)$ & $\begin{array}{c}3 \text { years, } \\
\$ 100,000(\$ 18- \\
1.3-401) \\
\end{array}$ \\
\hline $\begin{array}{l}\text { Connecticut } \\
\text { (C.G.S.A.) }\end{array}$ & $\begin{array}{l}\$ 2,000 \text { or } \\
\text { more } \\
(\$ 53 a-124)\end{array}$ & $\begin{array}{c}5 \text { years, } \\
\$ 5,000 \\
(\$ 53 a-35 a) \\
(\$ 53 a-41) \\
\end{array}$ & $\begin{array}{c}\$ 1,501 \text { or more } \\
(\$ 53 a-115)\end{array}$ & $\begin{array}{c}5 \text { years, } \$ 5,000 \\
(\$ 53 a-35 a) \\
(\$ 53 a-41)\end{array}$ & $(\$ 53 a-107)$ & $\begin{array}{c}1 \text { year, } \$ 2,000 \\
(\$ 53 a-26) \\
(\$ 53 a-42)\end{array}$ \\
\hline $\begin{array}{c}\text { Delaware } \\
\text { (11 Del. C.) }\end{array}$ & $\begin{array}{c}\$ 1,500 \text { or } \\
\text { more }(\$ 841)\end{array}$ & $\begin{array}{c}2 \text { years, value } \\
\text { of property } \\
(\S 4205) \\
(\S 4106)\end{array}$ & $\begin{array}{c}\text { More than } \\
\$ 1,000(\$ 811)\end{array}$ & $\begin{array}{c}1 \text { year, } \$ 2,300 \\
(\$ 4206)\end{array}$ & $(\S 823)$ & $\begin{array}{c}1 \text { year, } \$ 2,300 \\
(\$ 4206)\end{array}$ \\
\hline $\begin{array}{c}\text { District of } \\
\text { Columbia } \\
\text { (DC ST) }\end{array}$ & $\begin{array}{c}\$ 1000 \text { or } \\
\text { more }(\$ 22- \\
3212)\end{array}$ & $\begin{array}{c}10 \text { years, } \\
\$ 25,000 \\
(\$ 22-3212) \\
(\$ 22- \\
3571.01)\end{array}$ & $\begin{array}{c}\text { Defacing } \\
\text { Public or } \\
\text { Private } \\
\text { Property } \\
(\$ 22-3312.01)\end{array}$ & $\begin{array}{c}180 \text { days, at } \\
\text { least } \$ 250, \\
\$ 1,000 \mathrm{max} \\
(\$ 22-3312.04) \\
(\$ 22-3571.01)\end{array}$ & $(\S 22-3301)$ & $\begin{array}{c}1 \text { year, } \$ 2,500 \\
(\$ 22-3301) \\
(\$ 22-3571.01)\end{array}$ \\
\hline
\end{tabular}


Winter 2015]

IP AS VANDALISM

361

\begin{tabular}{|c|c|c|c|c|c|c|}
\hline $\begin{array}{l}\text { Florida } \\
\text { (F.S.A.) }\end{array}$ & $\begin{array}{c}\$ 300-\$ 4,999 \\
(\$ 812.014)\end{array}$ & $\begin{array}{c}5 \text { years, } \\
\$ 5,000 \\
(\$ 775.082) \\
(\$ 775.083) \\
\end{array}$ & $\begin{array}{c}\$ 1,000.01 \text { or } \\
\text { more } \\
(\$ 806.13)\end{array}$ & $\begin{array}{c}5 \text { years, } \$ 5,000 \\
(\$ 775.082) \\
(\$ 860.13) \\
(\$ 775.083) \\
\end{array}$ & $(\$ 810.09)$ & $\begin{array}{c}1 \text { year, } \$ 1,000 \\
(\$ 775.082) \\
(\$ 775.083)\end{array}$ \\
\hline $\begin{array}{c}\text { Georgia } \\
\text { (Ga. Code } \\
\text { Ann.) } \\
\end{array}$ & $\begin{array}{c}\$ 1500.01- \\
\$ 4,999 \\
(\$ 16-8-12) \\
\end{array}$ & $\begin{array}{c}5 \text { years, min } \\
\$ 1,000 \\
(\$ 16-8-12)\end{array}$ & $\begin{array}{c}\text { More than } \\
\$ 500 \\
(\$ 16-7-23) \\
\end{array}$ & $\begin{array}{c}5 \text { years } \\
(\S 16-7-22)\end{array}$ & $\begin{array}{c}\$ 500 \text { or less } \\
(\$ 16-7-21)\end{array}$ & $\begin{array}{c}12 \text { months, } \\
\$ 1,000 \\
(\$ 17-10-3) \\
\end{array}$ \\
\hline $\begin{array}{l}\text { Hawaii } \\
\text { (HRS) }\end{array}$ & $\begin{array}{c}\$ 300.01 \\
(\$ 708-831)\end{array}$ & $\begin{array}{c}5 \text { years, } \\
\$ 10,000+ \\
\$ 1,000 \mathrm{~min} \\
(\$ 706-660) \\
(\$ 706-640) \\
(\$ 708-831) \\
\end{array}$ & $\begin{array}{c}\$ 1500.01 \\
(\$ 708-820)\end{array}$ & $\begin{array}{c}5 \text { years, } \\
\$ 10,000(\$ 706- \\
660)(\$ 706- \\
640)\end{array}$ & $(\$ 708-813)$ & $\begin{array}{c}1 \text { year, } \$ 2,000 \\
(\$ 706-663) \\
(\$ 706-640)\end{array}$ \\
\hline $\begin{array}{l}\text { Idaho } \\
\text { (I.C.) }\end{array}$ & $\begin{array}{c}\$ 1,000.01 \text { or } \\
\text { more } \\
(\$ 18-2407)\end{array}$ & $\begin{array}{c}20 \text { years, } \\
\$ 10,000 \\
(\$ 18-2408) \\
\end{array}$ & $\begin{array}{c}\$ 1,000.01 \text { or } \\
\text { more } \\
(\$ 18-7001)\end{array}$ & $\begin{array}{c}1 \text { year, } \$ 1,000 \\
(\$ 08-7001)\end{array}$ & $(\S 18-7011)$ & $\begin{array}{c}6 \text { months, } \\
\$ 1,000 \\
(\$ 18-7011) \\
\end{array}$ \\
\hline $\begin{array}{l}\text { Illinois } \\
\text { (ILCS) }\end{array}$ & $\begin{array}{c}\$ 500.01- \\
\$ 10,000 \\
(720 \text { ILCS } \\
5 / 16-1)\end{array}$ & $\begin{array}{c}5 \text { years, } \\
\$ 25,000(720 \\
\text { ILCS } 5 / 5-7.5- \\
40)(720 \\
\text { ILCS } 5 / 5-4.5- \\
50)\end{array}$ & $\begin{array}{c}\$ 300.01- \\
\$ 10,000 \\
(720 \text { ILCS } \\
5 / 21-1)\end{array}$ & $\begin{array}{c}3 \text { years, } \\
\$ 25,000(720 \\
\text { ILCS 5/5-7.5- } \\
45)(720 \text { ILCS } \\
5 / 5-4.5-50)\end{array}$ & $\begin{array}{c}\text { (720 ILCS } \\
5 / 21-3)\end{array}$ & $\begin{array}{c}1 \text { year, } \$ 2,500 \\
(720 \text { ILCS } 5 / 5- \\
4.5-55)\end{array}$ \\
\hline $\begin{array}{l}\text { Indiana } \\
\text { (IC) }\end{array}$ & $\begin{array}{c}\$ 750-\$ 49,999 \\
(\$ 35-43-4-2)\end{array}$ & $\begin{array}{c}3 \text { years, } \\
\$ 10,000 \\
(\$ 35-50-2-7) \\
\end{array}$ & $\begin{array}{c}\$ 750-\$ 49,999 \\
(\$ 35-43-1-2)\end{array}$ & $\begin{array}{c}1 \text { year, } \$ 5,000 \\
(\$ 35-50-3-2)\end{array}$ & $\begin{array}{c}\$ 750- \\
\$ 49,999 \\
(\$ 35-43-2-2) \\
\end{array}$ & $\begin{array}{c}3 \text { years, } \\
\$ 10,000(\$ 35- \\
50-2-7) \\
\end{array}$ \\
\hline $\begin{array}{c}\text { Iowa } \\
\text { (I.C.A.) }\end{array}$ & $\begin{array}{c}\$ 1,000.01- \\
\$ 10,000 \\
(\$ 714.2) \\
\end{array}$ & $\begin{array}{c}5 \text { years, } \\
\$ 7,500 \\
(\$ 902.9) \\
\end{array}$ & $\begin{array}{c}\$ 1,000.01- \\
\$ 10,000 \\
(\$ 716.4) \\
\end{array}$ & $\begin{array}{c}5 \text { years, } \$ 7,500 \\
(\$ 902.9)\end{array}$ & $\begin{array}{c}\$ 200.01 \text { or } \\
\text { more } \\
(\$ 716.8)\end{array}$ & $\begin{array}{c}1 \text { year, } \$ 1,875 \\
(\$ 903.1)\end{array}$ \\
\hline $\begin{array}{l}\text { Kansas } \\
\text { (K.S.A.) }\end{array}$ & $\begin{array}{c}\$ 1,000- \\
\$ 24,999 \\
(\$ 21-5801)\end{array}$ & $\begin{array}{c}\$ 100,000 \\
(\$ 21-6611) \\
(\$ 21-6804)\end{array}$ & $\begin{array}{c}\$ 1,000- \\
\$ 24,999 \\
(\$ 21-5813)\end{array}$ & $\begin{array}{c}\$ 100,000(\$ 21- \\
6611)(\$ 21- \\
6804)\end{array}$ & $(21-5808)$ & $\begin{array}{c}6 \text { months, } \\
\$ 1,000 \\
(\$ 21-6602) \\
(\$ 21-6611) \\
\end{array}$ \\
\hline $\begin{array}{c}\text { Kentucky } \\
(\text { KRS) }\end{array}$ & $\begin{array}{c}\$ 500-\$ 9,999 \\
(\$ 514.030)\end{array}$ & $\begin{array}{c}5 \text { years, } \\
\$ 10,000 \\
(\$ 532.020) \\
(\$ 534.030) \\
\end{array}$ & $\begin{array}{c}\$ 1,000 \text { or more } \\
(\$ 512.020)\end{array}$ & $\begin{array}{c}\text { 5 years, } \\
\$ 10,000 \\
(\$ 532.020) \\
(\$ 534.030) \\
\end{array}$ & $(\$ 511.060)$ & $\begin{array}{c}1 \text { year, } \$ 500 \\
(\$ 532.020) \\
(\$ 534.040)\end{array}$ \\
\hline $\begin{array}{l}\text { Louisiana } \\
\text { (LSA-RS) }\end{array}$ & $\begin{array}{c}\$ 1,500 \text { or } \\
\text { more } \\
(\text { LSA-R.S. } \\
\$ 67)\end{array}$ & $\begin{array}{c}10 \text { years, } \\
\$ 3,000 \\
\text { (LSA-R.S. } \\
\$ 67)\end{array}$ & $\begin{array}{c}\text { Simple } \\
\text { criminal } \\
\text { damage at } \\
\text { property } \$ 500- \\
\$ 49,999 \\
(\text { LSA-R.S. } \\
\S 14: 56) \\
\end{array}$ & $\begin{array}{c}2 \text { years, } \$ 1,000 \\
\text { (LSA-R.S. } \\
\$ 14-56)\end{array}$ & $\begin{array}{c}\text { (LSA-R.S. } \\
\S 63)\end{array}$ & $\begin{array}{c}30 \text { days, } \$ 500 \\
\text { (LSA-R.S. } \$ 63)\end{array}$ \\
\hline $\begin{array}{c}\text { Maine } \\
\text { (Title } 32 \\
\text { M.R.S.A.) }\end{array}$ & $\begin{array}{c}\$ 1,000.01- \\
\$ 10,000 \\
(\$ 353)\end{array}$ & $\begin{array}{l}5 \text { years, } \\
\$ 5,000 \\
(\$ 1252) \\
(\$ 1301)\end{array}$ & $\begin{array}{l}\text { More than } \\
\$ 2000 \\
(\S 805)\end{array}$ & $\begin{array}{c}5 \text { years, } \$ 5,000 \\
(\$ 1252) \\
(\$ 1301)\end{array}$ & $(\S 402)$ & $\begin{array}{c}1 \text { year, } \$ 2,000 \\
(\$ 1252) \\
(\$ 1301)\end{array}$ \\
\hline
\end{tabular}




\begin{tabular}{|c|c|c|c|c|c|c|}
\hline $\begin{array}{c}\text { Maryland } \\
\text { (MD Code, } \\
\text { Criminal Law) }\end{array}$ & $\begin{array}{c}\$ 1,000- \\
\$ 9,999 \\
(\$ 7-104)\end{array}$ & $\begin{array}{l}10 \text { years, } \\
\$ 10,000 \\
(\$ 7-104)\end{array}$ & $\begin{array}{c}\$ 1,000 \text { or more } \\
(\$ 6-301)\end{array}$ & $\begin{array}{c}3 \text { years, } \$ 2,500 \\
(\$ 6-301)\end{array}$ & $(\S 6-402)$ & $\begin{array}{c}90 \text { days, } \$ 500 \\
(\$ 6-402)\end{array}$ \\
\hline $\begin{array}{l}\text { Massachusetts } \\
\text { (M.G.L.A.) }\end{array}$ & $\begin{array}{l}\text { More than } \\
\$ 250 \\
(266 \S 30)\end{array}$ & $\begin{array}{c}5 \text { years OR } 2 \\
\text { years, } \\
\$ 25,000 \\
(266 \$ 30)\end{array}$ & $(266 \S 127)$ & $\begin{array}{c}10 \text { years, Or } \\
\text { the greater of } \\
\$ 3,000 \text { or } \$ 3 x \\
\text { value AND } 2.5 \\
\text { years }\end{array}$ & $(266 \S 120)$ & $\begin{array}{c}30 \text { days, } \$ 100 \\
(266 \$ 120)\end{array}$ \\
\hline $\begin{array}{l}\text { Michigan } \\
\text { (M.C.L.A.) }\end{array}$ & $\begin{array}{c}\$ 1,000- \\
\$ 19,999 \\
(\$ 750.356)\end{array}$ & $\begin{array}{c}5 \text { years, } \\
\text { greater of } \\
\$ 10,000 \text { or } 3 x \\
\text { value } \\
(\$ 750.356) \\
\end{array}$ & $\begin{array}{c}\$ 1,000- \\
\$ 19,999 \\
(\$ 750.377 \mathrm{a})\end{array}$ & $\begin{array}{c}5 \text { years, greater } \\
\text { of } \$ 10,000 \text { or } \\
3 x \text { value } \\
(\$ 750.377 a)\end{array}$ & $(\$ 750.552)$ & $\begin{array}{c}30 \text { days, } \$ 250 \\
(\$ 750.552)\end{array}$ \\
\hline $\begin{array}{l}\text { Minnesota } \\
\text { (M.S.A.) }\end{array}$ & $\begin{array}{c}\$ 1,000.01- \\
\$ 4,999 \\
(\$ 609.52) \\
\end{array}$ & $\begin{array}{c}5 \text { years, } \\
\$ 10,000 \\
(\$ 609.52) \\
\end{array}$ & $\begin{array}{c}\text { More than } \\
\$ 1,000 \\
(\$ 609.595) \\
\end{array}$ & $\begin{array}{c}5 \text { years, } \\
\$ 10,000 \\
(\$ 609.595) \\
\end{array}$ & $(\$ 609.605)$ & $\begin{array}{c}90 \text { days, } \$ 1,000 \\
(\$ 609.03)\end{array}$ \\
\hline $\begin{array}{c}\text { Mississippi } \\
\text { (Miss. Code } \\
\text { Ann.) }\end{array}$ & $\begin{array}{c}\$ 1,000- \\
\$ 4,999 \\
(\$ 97-17-41)\end{array}$ & $\begin{array}{c}5 \text { years, } \\
\$ 10,000 \\
(\$ 97-17-41)\end{array}$ & $\begin{array}{c}\$ 1,000.01- \\
\$ 4,999 \\
(\$ 97-17-67)\end{array}$ & $\begin{array}{c}5 \text { years, } \\
\$ 10,000(\S 97- \\
17-67) \\
\end{array}$ & $(\S 97-17-87)$ & $\begin{array}{c}6 \text { months, } \$ 500 \\
(\$ 97-17-87)\end{array}$ \\
\hline $\begin{array}{l}\text { Missouri } \\
\text { (RSMo) }\end{array}$ & $\begin{array}{c}\$ 500-\$ 24,999 \\
(\$ 570.030)\end{array}$ & $\begin{array}{c}7 \text { years, } \\
\text { greater of } \\
\$ 5,000 \text { or } 2 \mathrm{x} \\
\text { value } \\
(\$ 570.030) \\
(\$ 558.011) \\
(\$ 560.011)\end{array}$ & $\begin{array}{c}\text { Property } \\
\text { Damage 1st } \\
\text { Degree More } \\
\text { than } \$ 750 \\
(\$ 569.100)\end{array}$ & $\begin{array}{c}4 \text { years, greater } \\
\text { of } \$ 5,000 \text { or } 2 \mathrm{x} \\
\text { value } \\
(\$ 558.011) \\
(\$ 569.100) \\
(\$ 560.011)\end{array}$ & $(\S 569.140)$ & $\begin{array}{c}6 \text { months, } \$ 500 \\
(\$ 558.011) \\
(\$ 560.016)\end{array}$ \\
\hline $\begin{array}{c}\text { Montana } \\
\text { (MCA) }\end{array}$ & $\begin{array}{c}\text { More than } \\
\$ 1,500 \\
(\$ 45-6-301)\end{array}$ & $\begin{array}{c}10 \text { years, } \\
\$ 50,000 \\
(\$ 45-6-301)\end{array}$ & $\begin{array}{c}\text { More than } \\
\$ 1,500 \\
(\$ 45-6-101)\end{array}$ & $\begin{array}{c}10 \text { years, } \\
\$ 50,000 \\
(\$ 45-6-101)\end{array}$ & $(\$ 45-6-203)$ & $\begin{array}{c}6 \text { months, } \$ 500 \\
(\$ 45-6-203)\end{array}$ \\
\hline $\begin{array}{c}\text { Nebraska } \\
\text { (Neb. Rev. St.) }\end{array}$ & $\begin{array}{c}\text { More than } \\
\$ 1,500 \\
(\$ 28-518) \\
\end{array}$ & $\begin{array}{c}20 \text { years, } \\
\$ 25,000(\$ 28- \\
105) \\
\end{array}$ & $\begin{array}{c}\$ 1,500 \text { or more } \\
(\$ 28-519)\end{array}$ & $\begin{array}{c}5 \text { years, } \\
\$ 10,000 \\
(\$ 28-105) \\
\end{array}$ & $(\S 28-520)$ & $\begin{array}{c}1 \text { year, } \$ 1,000 \\
(\$ 28-106)\end{array}$ \\
\hline $\begin{array}{c}\text { Nevada } \\
(\text { N.R.S.) })^{142}\end{array}$ & $\begin{array}{c}\$ 650.01- \\
\$ 3,499 \\
(\$ 205.222)\end{array}$ & $\begin{array}{c}5 \text { years, } \\
\$ 10,000 \\
(\$ 193.130)\end{array}$ & $\begin{array}{c}\$ 250-\$ 4,999 \\
(\$ 206.330)\end{array}$ & $\begin{array}{c}364 \text { days, } \\
\$ 2,000 \\
(\$ 193.140)\end{array}$ & $(\S 206.140)$ & $\begin{array}{c}\text { Value of } \\
\text { damage, at least } \\
6 \text { months, } \\
\$ 1,000 \\
(\$ 206.140) \\
(\$ 193.150)\end{array}$ \\
\hline $\begin{array}{c}\text { New } \\
\text { Hampshire } \\
\text { (N.H. Rev. } \\
\quad \text { Stat) }\end{array}$ & $\begin{array}{c}\text { More than } \\
\$ 1,500 \\
(\$ 637: 11)\end{array}$ & $\begin{array}{c}15 \text { years, } \\
\$ 4,000 \\
(\$ 651: 2)\end{array}$ & $\begin{array}{c}\text { More than } \\
\$ 1,500 \\
(\$ 634: 2)\end{array}$ & $\begin{array}{c}7 \text { years, } \$ 4,000 \\
(\$ 651: 2)\end{array}$ & $\begin{array}{c}\text { More than } \\
\$ 1,500 \\
(\$ 635: 2)\end{array}$ & $\begin{array}{c}7 \text { years, } \$ 4,000 \\
(\$ 651: 2)\end{array}$ \\
\hline
\end{tabular}

142. Nevada has separate statutes for theft and larceny; larceny statutes are cited herein. 
Winter 2015]

IP AS VANDALISM

363

\begin{tabular}{|c|c|c|c|c|c|c|}
\hline $\begin{array}{l}\text { New Jersey } \\
\text { (N.J.S.A.) }\end{array}$ & $\begin{array}{c}\$ 500.01- \\
\$ 74,999 \\
(\$ 2 \mathrm{C}: 20-2)\end{array}$ & $\begin{array}{c}5 \text { years, } \\
\$ 15,000 \\
(\S 2 \mathrm{C}: 43-6) \\
(\S 2 \mathrm{C}: 43-3) \\
\end{array}$ & $\begin{array}{l}\$ 2,000 \text { or more } \\
(\$ 2 \mathrm{C}: 17-3)\end{array}$ & $\begin{array}{c}5 \text { years, } \\
\$ 15,000 \\
(\S 2 \mathrm{C}: 43-6) \\
(\$ 2 \mathrm{C}: 43-3) \\
\end{array}$ & $(\S 2 \mathrm{C}: 18-3)$ & $\begin{array}{l}18 \text { months, } \\
\$ 10,000 \\
(\S 2 \mathrm{C}: 43-6) \\
(\S 2 \mathrm{C}: 43-3) \\
\end{array}$ \\
\hline $\begin{array}{l}\text { New Mexico } \\
\text { (N.M.S.A.) }\end{array}$ & $\begin{array}{c}\$ 2,500.01- \\
\$ 25,000 \\
(\$ 30-16-1) \\
\end{array}$ & $\begin{array}{c}3 \text { years, } \\
\$ 5,000 \\
(\$ 31-18-15) \\
\end{array}$ & $\begin{array}{l}\text { More than } \\
\$ 1,000 \\
(\$ 30-15-1) \\
\end{array}$ & $\begin{array}{c}18 \text { months, } \\
\$ 5,000 \\
(\$ 31-18-15)\end{array}$ & $\begin{array}{l}\text { Any damage } \\
\text { to property } \\
(\S 30-14-1.1)\end{array}$ & $\begin{array}{c}\text { Double } \\
\text { appraised value } \\
\text { of damage }\end{array}$ \\
\hline $\begin{array}{l}\text { New York } \\
\text { (McKinney’s } \\
\text { Penal Law) }\end{array}$ & $\begin{array}{l}\text { More than } \\
\$ 1,000 \\
(\$ 155.30)\end{array}$ & \begin{tabular}{|c|}
4 years \\
$(\$ 70.00)$ (no \\
fine specified \\
$\S 80.00)$ \\
\end{tabular} & $\begin{array}{l}\text { More than } \\
\$ 1,500 \\
(\$ 145.10)\end{array}$ & $\begin{array}{c}7 \text { years } \\
(\$ 70.00) \text { (no } \\
\text { fine specified } \\
\$ 80.00) \\
\end{array}$ & $(\S 140.15)$ & $\begin{array}{c}1 \text { year, } \$ 1,000 \\
(\$ 70.15) \\
(\$ 80.00)\end{array}$ \\
\hline $\begin{array}{c}\text { North Carolina } \\
\text { (N.C.G.S.A.) }\end{array}$ & $\begin{array}{l}\text { More than } \\
\$ 1,000 \\
(\$ 14-72)\end{array}$ & $\begin{array}{c}8 \text { years } \\
(\$ 15 \mathrm{~A}- \\
1340.17) \\
\text { fines appear } \\
\text { to be } \\
\text { discretionary } \\
(\$ 15 \mathrm{~A}-1361 \\
\text { et seq. })\end{array}$ & $\begin{array}{c}\text { Vandalism } \\
\text { statutes are } \\
\text { specific to } \\
\text { agriculture, } \\
\text { public } \\
\text { facilities, and } \\
\text { other unique } \\
\text { categories (e.g. } \\
\S 14-132) \\
\end{array}$ & $\begin{array}{c}6 \text { months, } \\
\$ 1,000 \\
(\S 14-3) \\
(\S 15 \mathrm{~A}- \\
1340.23)\end{array}$ & $\begin{array}{l}\text { More than } \\
\quad \$ 200 \\
(\$ 14-160)\end{array}$ & $\begin{array}{c}1 \text { year, } \\
\text { discretionary } \\
\text { fine }(\$ 14-3) \\
(\S 15 \mathrm{~A}-1340.23)\end{array}$ \\
\hline $\begin{array}{l}\text { North Dakota } \\
\text { (NDCC) }\end{array}$ & $\begin{array}{c}\$ 1,000.01 \text { or } \\
\text { more } \\
(\$ 12.1-23-05) \\
\end{array}$ & $\begin{array}{c}5 \text { years, } \\
\$ 10,000 \\
(\$ 12.0-32-01) \\
\end{array}$ & $\begin{array}{c}\$ 2,000.01- \\
\$ 10,000 \\
(\$ 12.1-21-05) \\
\end{array}$ & $\begin{array}{c}5 \text { years, } \\
\$ 10,000 \\
(\$ 12.0-32-01) \\
\end{array}$ & $\begin{array}{c}(\$ 12.1-22- \\
03)\end{array}$ & $\begin{array}{c}5 \text { years, } \$ 10,000 \\
(\$ 12.0-32-01)\end{array}$ \\
\hline Ohio (R.C.) & $\begin{array}{c}\$ 1,000- \\
\$ 7,499 \\
(\$ 2913.02)\end{array}$ & $\begin{array}{c}1 \text { year, } \\
\$ 2,500 \\
(\$ 2929.14) \\
(\$ 2929.18) \\
\end{array}$ & $\begin{array}{c}\$ 1,000 \text { or more } \\
(\$ 2909.05)\end{array}$ & $\begin{array}{c}1 \text { year, } \$ 2,500 \\
(\$ 2929.14) \\
(\$ 2929.18) \\
(\$ 2905.05) \\
\end{array}$ & $(\$ 2911.21)$ & $\begin{array}{c}30 \text { days, } \$ 250 \\
(\$ 2929.24) \\
(\$ 2929.28)\end{array}$ \\
\hline $\begin{array}{c}\text { Oklahoma } \\
\text { (21 Okl. Stat. } \\
\text { Ann) } \\
\end{array}$ & $\begin{array}{c}\$ 500 \text { or more } \\
(\$ 1705)\end{array}$ & $\begin{array}{l}5 \text { years, } \\
\$ 5,000 \\
(\$ 1705)\end{array}$ & $\begin{array}{c}\$ 1,000 \text { or more } \\
(\$ 1760)\end{array}$ & $\begin{array}{c}2 \text { years, } \$ 1,000 \\
(\$ 9)\end{array}$ & $(\S 1835)$ & $\begin{array}{c}30 \text { days, } \$ 500 \\
(\$ 1835)\end{array}$ \\
\hline $\begin{array}{l}\text { Oregon } \\
\text { (O.R.S.) }\end{array}$ & $\begin{array}{l}\$ 1,000 \text { or } \\
\text { more } \\
(\$ 164.055)\end{array}$ & $\begin{array}{c}\text { 5 years, } \\
\$ 125,000 \\
(\$ 161.605) \\
(\$ 161.625) \\
\end{array}$ & $\begin{array}{c}\$ 1,000.01 \text { or } \\
\text { more } \\
(\$ 164.365)\end{array}$ & $\begin{array}{c}5 \text { years, } \\
\$ 125,000 \\
(\$ 161.605) \\
(\$ 161.625) \\
\end{array}$ & $(\S 164.255)$ & $\begin{array}{c}1 \text { year, } \$ 6,250 \\
(\$ 161.615) \\
(\$ 161.635)\end{array}$ \\
\hline $\begin{array}{l}\text { Pennsylvania } \\
\text { (Pa.C.S.A.) }\end{array}$ & $\begin{array}{c}\$ 2,000.01 \text { or } \\
\text { more } \\
(\$ 3903)\end{array}$ & $\begin{array}{l}7 \text { years, } \\
\$ 15,000 \\
(\$ 1103) \\
(\$ 1101) \\
\end{array}$ & $\begin{array}{c}\$ 1000.01- \\
\$ 5,000 \\
(\$ 3304)\end{array}$ & $\begin{array}{c}2 \text { years, } \$ 5,000 \\
(\$ 1103) \\
(\$ 1101)\end{array}$ & $(\S 3503)$ & $\begin{array}{c}1 \text { year, } \$ 2,500 \\
(\$ 1103) \\
(\$ 1101)\end{array}$ \\
\hline $\begin{array}{l}\text { Rhode Island } \\
\text { (Gen. Laws) }\end{array}$ & $\begin{array}{c}\$ 1,500.01 \text { or } \\
\text { more } \\
(\$ 11-41-5) \\
\end{array}$ & $\begin{array}{c}10 \text { years, } \\
\$ 5,000(\$ 11- \\
41-5) \\
\end{array}$ & $(\$ 11-44-1)$ & $\begin{array}{c}1 \text { year, } \$ 1,000 \\
(\$ 11-44-1)\end{array}$ & $(\$ 11-44-26)$ & $\begin{array}{c}1 \text { year, } \$ 1,000 \\
(\$ 11-44-26)\end{array}$ \\
\hline $\begin{array}{l}\text { South Carolina } \\
\text { (Code) }\end{array}$ & $\begin{array}{c}\$ 2,000.01- \\
\$ 9,999.99 \\
(\$ 16-13-30)\end{array}$ & $\begin{array}{c}5 \text { years, } \\
\text { mandatory } \\
\text { discretionary } \\
\text { fine }(\S 16-13- \\
30) \\
\end{array}$ & $\begin{array}{c}\$ 2,000.01- \\
\$ 9,999 \\
(\$ 16-11-520)\end{array}$ & $\begin{array}{c}5 \text { years, } \\
\text { mandatory } \\
\text { discretionary } \\
\text { fine } \\
(\S 16-11-520) \\
\end{array}$ & $\begin{array}{c}(\$ 16-11- \\
600)\end{array}$ & $\begin{array}{l}30 \text { days, } \$ 100 \\
(\$ 16-11-520)\end{array}$ \\
\hline
\end{tabular}


[Vol. 18:331

\begin{tabular}{|c|c|c|c|c|c|c|}
\hline $\begin{array}{c}\text { South Dakota } \\
\text { (SDCL) }\end{array}$ & $\begin{array}{c}\$ 2,500.01- \\
\$ 5,000 \\
(\$ 22-30 \mathrm{~A}-17)\end{array}$ & $\begin{array}{c}5 \text { years, } \\
\$ 10,000(\$ 22- \\
6-1)\end{array}$ & $\begin{array}{c}\$ 2,500.01- \\
\$ 5,000 \\
(\$ 22-34-1) \\
\end{array}$ & $\begin{array}{c}5 \text { years, } \\
\$ 10,000(\$ 22- \\
6-1)\end{array}$ & $(\S 22-35-5)$ & $\begin{array}{c}1 \text { year, } \$ 2,000 \\
(\$ 22-6-2)\end{array}$ \\
\hline $\begin{array}{l}\text { Tennessee } \\
\text { (T.C.A.) }\end{array}$ & $\begin{array}{c}\$ 1,000- \\
\$ 9,999 \\
(\$ 39-14-105)\end{array}$ & $\begin{array}{c}12 \text { years, } \\
\$ 5,000(\$ 40- \\
35-111)\end{array}$ & $\begin{array}{c}\$ 1,000-\$ 9,999 \\
(\$ 39-14-105)\end{array}$ & $\begin{array}{c}12 \text { years, } \\
\$ 5,000(\$ 40- \\
35-111)\end{array}$ & $\begin{array}{c}(\$ 39-14- \\
406)\end{array}$ & $\begin{array}{c}6 \text { months, } \$ 500 \\
(\$ 40-35-111)\end{array}$ \\
\hline $\begin{array}{c}\text { Texas } \\
\text { (V.T.C.A.) }\end{array}$ & $\begin{array}{l}\$ 1,500- \\
\$ 19,999 \\
(\$ 31.03) \\
\end{array}$ & $\begin{array}{l}2 \text { years, } \\
\$ 10,000 \\
(\$ 12.35)\end{array}$ & $\begin{array}{l}\$ 1,500- \\
\$ 19,999 \\
(\$ 28.03)\end{array}$ & $\begin{array}{l}2 \text { years, } \\
\$ 10,000 \\
(\$ 12.35)\end{array}$ & $(\$ 30.05)$ & $\begin{array}{c}1 \text { year, } \$ 4,000 \\
(\$ 12.21)\end{array}$ \\
\hline $\begin{array}{c}\text { Utah } \\
\text { (U.C.A.) }\end{array}$ & $\begin{array}{c}\$ 1,500- \\
\$ 4,999 \\
(\$ 76-6-412)\end{array}$ & $\begin{array}{c}5 \text { years, } \\
\$ 5,000(\$ 76- \\
3-203) \\
(\$ 76-3-301) \\
\end{array}$ & $\begin{array}{c}\$ 1,500-\$ 4,999 \\
(\$ 76-6-106)\end{array}$ & $\begin{array}{c}5 \text { years, } \$ 5,000 \\
(\$ 76-3-203) \\
(\$ 76-3-301)\end{array}$ & (§76-6-206) & $\begin{array}{c}1 \text { year, } \$ 2,500 \\
(\S 76-3-204) \\
(\S 76-3-301)\end{array}$ \\
\hline $\begin{array}{l}\text { Vermont } \\
\text { (V.S.A.) }\end{array}$ & $\begin{array}{c}\$ 900.01 \text { or } \\
\text { more } \\
(\$ 2501) \\
\end{array}$ & $\begin{array}{c}10 \text { years, } \\
\$ 5,000 \\
(\$ 2501)\end{array}$ & $\begin{array}{c}\text { More than } \\
\$ 1,000(\$ 3701)\end{array}$ & $\begin{array}{c}5 \text { years, } \$ 5,000 \\
(\$ 3701)\end{array}$ & $(\S 3705)$ & $\begin{array}{c}3 \text { years, } \$ 2,000 \\
(\$ 3705)\end{array}$ \\
\hline $\begin{array}{c}\text { Virginia } \\
\text { (VA Code } \\
\text { Ann.) }\end{array}$ & $\begin{array}{l}\$ 5 \text { or more } \\
\text { from the } \\
\text { person, } \$ 200 \\
\text { or more not } \\
\text { from the } \\
\text { person } \\
(\$ 18.2-95) \\
\end{array}$ & $\begin{array}{c}20 \text { years, } \\
\$ 2,500 \\
(\$ 18.2-95)\end{array}$ & $\begin{array}{c}\$ 1,000 \text { or more } \\
(\$ 18.2-137)\end{array}$ & $\begin{array}{c}5 \text { years, OR } 2 \\
\text { years and } \\
\$ 2,500(\$ 18.2- \\
10)\end{array}$ & $(\S 18.2-121)$ & $\begin{array}{c}1 \text { year, } \\
\$ 2,500(\$ 18.2- \\
11)\end{array}$ \\
\hline $\begin{array}{l}\text { Washington } \\
\text { (RCWA) }\end{array}$ & $\begin{array}{c}\$ 750.01- \\
\$ 5,000 \\
(\$ 9 A .56 .030)\end{array}$ & $\begin{array}{c}5 \text { years, } \\
\$ 10,000 \\
(\$ 9 A .20 .020)\end{array}$ & $\begin{array}{c}\$ 750.01- \\
\$ 5,000 \\
(\$ 9 \mathrm{~A} .48 .080)\end{array}$ & $\begin{array}{c}5 \text { years, } \\
\$ 10,000 \\
(\$ 43.06 .230) \\
(\$ 9.92 .010)\end{array}$ & $\begin{array}{c}(\$ 9 \mathrm{~A} .52 .070 \\
)\end{array}$ & $\begin{array}{c}364 \text { days, } \\
\$ 5,000 \\
(\$ 9.92 .020)\end{array}$ \\
\hline $\begin{array}{l}\text { West Virginia } \\
\text { (W.Va. Code) }\end{array}$ & $\begin{array}{c}\$ 1,000 \text { or } \\
\text { more } \\
(\$ 61-3-13)\end{array}$ & $\begin{array}{c}10 \text { years, } \\
\$ 2,500 \\
(\$ 61-3-13) \\
\end{array}$ & $\begin{array}{c}\$ 2,500 \text { or more } \\
(\$ 61-3-30)\end{array}$ & $\begin{array}{c}10 \text { years, } \\
\$ 2,500(\$ 31-3- \\
30) \\
\end{array}$ & $(\$ 61-3 B-2)$ & $\begin{array}{c}12 \text { months, } \$ 500 \\
(\$ 61-3 \mathrm{~B}-2)\end{array}$ \\
\hline $\begin{array}{c}\text { Wisconsin } \\
\text { (W.S.A.) }\end{array}$ & $\begin{array}{c}\$ 2,500.01- \\
\$ 5,000 \\
(\$ 943.20)\end{array}$ & $\begin{array}{c}3 \text { years \& } 6 \\
\text { months, } \\
\$ 10,000 \\
(\$ 939.50)\end{array}$ & $\begin{array}{c}\text { More than } \\
\$ 2,500 \\
(\$ 943.01)\end{array}$ & $\begin{array}{c}3 \text { years \& } 6 \\
\text { months, } \\
\$ 10,000 \\
(\$ 939.50)\end{array}$ & $(\$ 943.13)$ & $\begin{array}{c}9 \text { months, } \\
\$ 10,000 \\
(\$ 939.51)\end{array}$ \\
\hline $\begin{array}{c}\text { Wyoming } \\
\text { (W.S.) }\end{array}$ & $\begin{array}{c}\$ 1,000 \text { or } \\
\text { more } \\
(\$ 6-3-402)\end{array}$ & $\begin{array}{c}10 \text { years, } \\
\$ 10,000(\$ 6- \\
3-402)\end{array}$ & $\begin{array}{c}\$ 1,000 \text { or more } \\
(\$ 6-3-201)\end{array}$ & $\begin{array}{c}10 \text { years, } \\
\$ 10,000 \\
(\$ 6-3-201)\end{array}$ & $(\$ 6-3-303)$ & $\begin{array}{c}6 \text { months, } \$ 750 \\
(\$ 6-3-303)\end{array}$ \\
\hline
\end{tabular}

